In search of performance effects of (in) direct industry science links

Bruno Cassiman, Reinhilde Veugelers and Pluvia Zuniga

DEPARTMENT OF MANAGERIAL ECONOMICS, STRATEGY AND INNOVATION (MSI) 


\title{
In Search of Performance Effects of (in) direct Industry Science Links
}

\author{
Bruno Cassiman ${ }^{1,3,4}$, Reinhilde Veugelers ${ }^{2,3,4}$, Pluvia Zuniga ${ }^{4,5}$ \\ ${ }^{1}$ IESE Business School, Universidad de Navarra, Barcelona (Spain) \\ ${ }^{2}$ European Commission (BEPA) \\ ${ }^{3}$ CEPR \\ ${ }^{4}$ Katholieke Universiteit Leuven ${ }^{*}$ \\ ${ }^{5}$ OECD
}

\begin{abstract}
Using patent data from the European Patent Office combined with firm level data, we evaluate the contribution of science linkages to the innovation performance of a firm at the patent level. We examine the effect of $i$ ) firm level linkages to science (firms active in publication and copublication), and ii) invention-specific linkages (patents with citations to scientific publications) on patent quality measures. Our results suggest that citations to scientific publications are not significant in explaining forward citations but are positively related to the scope of forward citations, both in terms of generality and geographical dispersion. Our main finding is that it is the linkage to science at the firm level that matters more for forward citations, except for patents in emerging technologies. In particular, non-science related patents of firms with firm level scientific linkages are more frequently and more quickly cited than comparable patents of firms without these science linkages.
\end{abstract}

Key words: Patent value, forward citation, science, industrial innovation

$$
\text { JEL : O32, O34, L13 }
$$

\footnotetext{
* Faculty of Economics and Applied Economics. Steunpunt O\&O Statistieken Dekenstraat 2, B-3000 Leuven, Belgium. Tel: +32 (0) 163257 93, fax: +32 (0) 163257 99. Support from KU Leuven Research Fund $(\mathrm{OT} / 04 / 07)$ is gratefully acknowledged.

Acknowledgements: We are grateful to Rene Belderbos, Dirk Czarnitzki, Alfonso Gambardella, Bart Van Looy, Yuichi Nagahara and Okazaki Teuro for remarks and suggestions, as well as participants to the EPFL Workshop on "Technology Transfer from Universities" in Lausanne and our discussant F. Lissoni. We also thank Colin Webb for useful comments and data provision (OECD-EPO Patent Citations).
} 


\section{Introduction}

An important and recurrent concern in economics has been to understand to what extent science explains technological progress. The answer to this question has profound implications on public policy, notably on the decision to fund public research by public institutions. The works by Jaffe (1989) and Adams (1990) have shown the importance of basic science (e.g. public research expenditures or outputs, e.g. publications) for economic growth while research by Acs, Audretsch and Feldman (1992) and others, have revealed the significant externalities stemming from local academic research on private R\&D and patenting. ${ }^{1}$ More recent studies suggest that the links to basic research by private firms have increased in the last decade and they manifest themselves today in multiple ways: growing university-industry collaboration (e.g. joint research, sharing of equipment and research tools) and contracting (Liebeskind et al, 1996; Darby and Zucker; 2001; Zucker et al, 2001; 2002), industry financing university research (OECD, 2004), increasing university spin-offs and licensing (Jansen and Thursby, 2001; Thursby and Thursby, 2002; Agrawal, 2002), mobility of university researchers (Kim et al, 2005; Geuna et al, 2005), and so forth. One of the most visible indications of growing science linkages by industry is found in the citations to science in patents (Narin et al, 1997; Hicks et al, 2001). For instance, Narin et al (1997) reported a threefold increase in the number of citations to academic literature in industrial patents in the United States through the mid 1990s. Accordingly, 73\% percent of the papers cited by industry patents were authored at academic, governmental, and other public institutions. ${ }^{2}$

These patterns evidence the increasing role played by in industry science links (ISL) in the search for competitive advantages by private firms. In spite of these growing connections to science our understanding of how these knowledge transmissions take place and how they modify the innovation process by private firms still remains unclear. Due to the highly specific nature of the know-how involved, only a select set of firms within specific industries are in fact formally dealing with scientific know-how offered by universities or other science institutes. For firms, science is more important as source of information for innovation in those

\footnotetext{
${ }^{1}$ The importance of academic research for industrial innovation has also been corroborated in survey based studies (Mansfield, 1991, 1995; Cohen, Nelson and Walsh, 2002).

2 Branstetter (2004) and Van Looy et al (2004) have also confirmed an increasing citation to academic publications in patents.
} 
technology fields where new breakthrough innovations can be achieved and transferred to new products and processes.

Breakthrough innovations are not the only economic benefits of science for industrial innovation. Research has shown that basic research influences in different and complex ways a firm's innovation process. By providing a map for research and codified forms of problem solving (Fleming, 1997; Fleming and Sorenson, 2004), science helps firms to avoid wasteful experimentation and focus on the most promising research paths, thereby increasing the productivity of internal research (Evenson and Kislev, 1976; Gambardella, 1995). ${ }^{4}$ It also serves to expand firms' absorptive capacity which allows firms to better screen and absorb external information (Cockburn and Henderson, 1998). Empirical research on ISL has shown that university-industry collaborations contribute to increase firms' research productivity, but that their contribution depends on firms' research capabilities and abilities to absorb scientific knowledge (Adams et al, 2001; Zucker et al, 2001; Zucker et al, 2002). One important shortcoming in this line of research is the lack of evaluation of the contribution of science to the quality of inventions and the specific mechanisms used by firms to link to scinece. This paper fills this gap.

Using patent data from the European Patent Office combined with firm level data, we evaluate the contribution of science linkages to the innovation performance of a firm at the patent level. We examine the effect of $i$ ) firm level linkages to science and ii) invention-specific linkages (citation in patents to science) on the quality of patents (as measured by forward patent citation). ${ }^{5}$ Our data consists of 1186 granted patents at the European Patent Office during 19952001 for a sample of 79 Flemish firms, identified as innovation active through the Eurostat CIS survey. Firms' scientific linkages are defined through several connections of the patenting firm with science, but are not necessarily directly related to the focal patent: $i)$ the number of assignees' scientific publications and/or co-publications with universities; ii) cooperation links with scientific institutes (as found in the Community Innovation Survey, 1998-2000); iii) use of public sources of information (ibid). As a measure of invention-specific scientific

\footnotetext{
${ }^{4}$ It contributes notably to overcome the difficulties attributed to the interdependency of technologies by reducing the landscape for research and maximizing thus the probability of discovery (Fleming and Sorenson, 2005).

${ }^{5}$ Following previous studies on patent quality (e.g. Harhoff et al, 1999; Reitzig, 2002), we use the number of forward citations received by focal patent as an indication of technological impact of inventions.
} 
connection, we use the scientific non-patent references cited by the (focal) patent (and found in the ISI-Web of Knowledge database).

We contribute to the literature in several aspects. First, we bring the literature on industry science links, which has focused mostly on determining who is engaged in ISL, to the level of studying the impact of ISL on the production of patents, i.e. is there a citation premium related to science linkage? Previous empirical research has shown that university patents, because they rely on more fundamental knowledge, are broader in scope and cited more frequently than private firm patents. By comparing private patents, we evaluate whether science linkages are also valuable for firms' by generating a citation premium.

Second, this paper attempts to expand the traditional analysis of determinants of quality of patents. Past research has shown the highly skewed distribution of quality (e.g. forward citation, renewal probability..) and economic value across patents within technologies (e.g. Scherer et al, 1999). As previously studied in the literature, the technological impact of patents is associated to the nature of the invention (attributes of the patent) and explained by the individuals who created that invention; e.g. experience or competences (Gay and Le Bas, 2003; Gambardella et $a l, 2005)$. However, researchers have often ignored the characteristics of the firms' or assignee as determinants in the quality analysis of patents. ${ }^{6}$ We claim that part of this skewed distribution of value of patents can be explained by the heterogeneity across the patent owners, in particular by the scientific capabilities of firms which allow them to decode advances in fundamental knowledge, and transfer basic research into a sequence of technology applications. These scientific capabilities of firms have been found to be equally skewed across firms, and are therefore an interesting candidate for being matched with the skewedness in patent citations.

Both descriptive and econometric analysis based on patent forward citations lead us to the following conclusions. First, our results suggest that citations to scientific publications (invention linkage to science) are less relevant in explaining forward citation but do relate to the scope of forward citation, both in terms of generality and geographical dispersion. ${ }^{7}$ This finding can be explained by the fact that patents citing science may contain more complex and

\footnotetext{
${ }^{6}$ Researches have attempted to control for the nature of the organization owning the patent; e.g. public and private organizations, universities versus corporations (Henderson et al, 1998; Scherer et al, 1999; Gambardella et al, 2005).

${ }^{7}$ The irrelevance of citation to science in the patent could be related to the findings previously reported by descriptive analyses that have cast doubt about the meaning of references to prior art in european patents (Meyer, 2000; Tijssen, 2001, 2002).
} 
fundamental knowledge that not easily diffuses. Any potential application of this knowledge, while indeed pioneering, is still far from the market. In contrast, a firm's proximity to science matters for patent quality: in particular, non-science related patents of firms with firm level scientific linkages are more frequently and more quickly cited than comparable patents of firms without these science linkages. This finding evidences the existence of internal spillovers within scientific-oriented firms (knowledge transfer across inventors) allowing these firms to write more valuable applied patents. It also suggests a process of innovation consisting in achieving high impact inventions building on more fundamental innovations (patents with non patent references), and transferring knowledge between inventors. In this way, this paper calls for a broader perspective in the evaluation of determinants of patent quality and contribution of science linkages at the firm level for innovation performance at the invention level. These findings describe the importance of firm-level science linkages for patent quality, in general. But when distinguishing according to the type of technology/industry, these firm-level science linkages seem to become less important when the technologies concerned are highly evolving technologies. In these cases, the invention-specific linkage to science seem to matter more.

The paper is organized as follows. Section 2 presents a summary of the literature and reviews previous empirical work. Section 3 describes our data and presents the empirical model while section 4 reports on the econometric results. The final section presents our conclusions and identifies some policy implications.

\section{Literature Background}

\subsection{The Growing Economic Importance of Science Links}

Using a diversity of methodologies, economists have since long attempted to asses the economic payoffs of basic research. Relying on the assumption of informational properties of basic research (non-rival and non-excludable; Arrow, 1962; Dasgupta and David, 1994), economists such as Griliches (1984) and Adams (1988; 1990) have shown the contribution of basic research (e.g. public research expenditures and scientific publications) to economic 
growth $^{8}$ This literature has demonstrated that knowledge flows from universities and public research centres make a substantial contribution to industrial innovation and, consequently, to public welfare. The rates of return to publicly funded research, for example, have been estimated between 20\% and 60\% (Salter and Martin, 2001).

Complementary research based on survey studies, has provided alternative estimates of the importance of basic research for industrial innovation and economic performance. For instance, relying on a survey of 76 U.S. firms in seven industries, Mansfield (1991) found that $11 \%$ of new product innovations and $9 \%$ of process innovations would not have been developed (without substantial delay) in the absence of recent academic research; which represented respectively $3 \%$ and $1 \%$ of sales. In addition, firms declared that $8 \%$ of their products were developed with substantial input from recent academic research (6\% of process innovations). ${ }^{9}$ Both the 1983 Yale Survey and the 1994 Carnegie Mellon Survey (CMS) of R\&D have shown the relevance of university research for innovation as conceived by managers. According to the CMS, American firms consider publishing by universities and patenting amongst the most important sources of knowledge to innovate Cohen et al, (2002). ${ }^{10}$ A different perception is found in European firms. The evidence from the Community Innovation Survey shows that only a small fraction of innovative enterprises consider scientific information, i.e. from universities and public research labs; as an important information source in their innovation process. In the Eurostat-Community Innovation Survey CIS-III (1999-2000), of all reporting innovative EU firms (excl UK) 4.5\% rated universities as important sources of information, while $68 \%$ indicated universities as not important at all. The CIS results also show the importance of science as information source to be highly firm size and technology specific. ${ }^{11}$

An additional indicator of the use of science constitutes the citation to scientific publications (non patent references) in patents. Using this indicator, Narin et al (1997) revealed three

\footnotetext{
${ }^{8}$ See Griliches (1995) for a review of the literature on estimates of private and social rates of return to private and publicly funded R\&D spending.

${ }^{9}$ Using these figures, Mansfield estimated the rate of return from academic research to be $28 \%$. In a follow-up study in 1998, Mansfield found that the academic research was becoming increasingly more important for industrial innovation: $15 \%$ of new products and 11\% of new processes could not have been developed in the absence of academic research, accounting in total for $5 \%$ of total sales. Mansfield second study also revealed that the time delay from academic research to industrial practice has shortened from 7 years to 6 .

${ }^{10}$ The results indicate that the key channels through which university research impacts industrial R\&D include published papers and reports, public conferences and meetings, informal information exchange, and consulting, amongst others.

${ }^{11}$ Concentrating on surveying Europe's largest industrial firms only, Arundel and Geuna (2004) find that public science is amongst the most important sources of technical knowledge for the innovative activities
} 
important patterns of science-linkages in the U.S. patents during the 1980s and 1990s: i) $a$ rapidly growing citation linkage to scientific research paper, ii) a strong national component in citation linkage, with each country's inventors preferentially citing papers authored in their own country, by a factor of between two and four; and iii) a highly skewed use of science across technology fields (see also McMillan et al, 2000; Callaert et al, 2003; Van Looy et al, 2004). ${ }^{12}$ In an attempt to disentangle the causes of these increasing linkages to science in the U.S. patents, Branstetter (2004) and Branstetter and Ogura (2005) found that these trends are best explained by a combination of the "changing composition" between scientific and technology research fertility and the "changing methods of invention" associated to an increased emphasis on the use of the knowledge generated by university-based scientists in later years. ${ }^{13}$ Nonetheless, their findings show that in spite of such dramatic rising, the new technological opportunities generated by academic research are found to be overwhelmingly concentrated in the "bionexus" area, that is, in the cross-field of biosciences and biotech-based technologies (Branstteter, 2004; Branstteter and Ogura, 2005). This finding persistently comes out in parallel studies (Callaert et al, 2003; Van Looy et al, 2004), suggesting in that way the crucial role of science for new technologies and related industries experiencing technological change (e.g. biotechnology and pharmaceuticals; information and telecommunication technologies, etc.).

\subsection{Uncovering the process through which science affects private innovation}

The available evidence indicates the wide firm heterogeneity in the importance of science links. Several strategic advantages have been identified to explain the firm's choice on whether to adopt or link to science. These include an increase of productivity and level of applied research effort (Evenson and Kislev, 1976), substantial gains in overall R\&D productivity (Henderson and Cockburn, 1994; Gambardella, 1995), the development of absorptive capacity (Cockburn and Henderson; 1998), labor cost reductions (Stern; 1999), amongst others. As they

\footnotetext{
${ }^{12}$ For patents in biotechnology, McMillan et al (2000) also report a strong national bias in the citation patterns, which can be explained by a more productive fertilization between national science and technology, an increase of scientific publication activity and a renewal of research strategy by private firms, more intensively focused on the opportunities given by open science.

${ }^{13}$ Changes in the distribution of patenting across technologies and changes in the distribution of publications across fields would appear to explain much more of the total variance in patent citations than does average changes across fields in per-patent citation behavior over time (Branstetter, 2004; Branstetter and Oruga, 2005).
} 
report successes and failures from basic research in a codified form of problem-solving, science increases the efficiency of private research (Arrow, 1962; Nelson, 1982; Dasgupta and David, 1994). The dissemination of scientific advances through open science reduces the degree of redundant effort providing useful information about technological opportunities, new industrial applications or re-combination of existing knowledge pieces (Sorenson and Fleming, 2004). As explained by Fleming and Sorenson (2004), science serves as a map for technological landscapes guiding private research in the direction of most promising technological venues avoiding thereby wasteful experimentation. ${ }^{14}$ Further, the adoption of open science -for instance through pro-publication incentives-(Cockburn \& Henderson,1998), helps firms to attract high quality academic researchers whose economic value might often be higher than their actual remuneration. Stern (1999) has shown that researchers looking for academic reputation, may want to pursue research projects leading to publications and are therefore, prompt to accept lower salaries in exchange of permission to keep up with scientific research. These researchers are twofold valued, they do not only imply important labor costs reductions for the firm, but also they constitute the "bridge" ('gatekeepers' and "boundary spanners") with the scientific or academic world. In spite of such paybacks, the adoption of science remains limited to a restricted set of firms, as the empirical evidence has detailed. Past research has shown that adoption of science is not costless, it is highly conditional on human capital and adoption of new organizational practices (Gambardella, 1995; Cockburn et al, 1999)..$^{15}$

Research seems to confirm that, contingent upon internal absorption capacity, the difficulties inherent to the transfer of tacit and complex knowledge often leads firms to look for collaborative agreements with science. ${ }^{16}$ Working jointly at the lab bench allows firms to capture tacit upfront research, absorb spillovers and de-codification of scientific knowledge generated by scientists at universities and public research centers, especially when tacit

\footnotetext{
14 According to Fleming and Sorenson (2004), scientific knowledge differs from that derived through 'local' search within the firm -which is closely related to firms' prior research activities-, namely because the scientific endeavour attempts to generate and test theories and fundamental ideas, whereas local search is focused on finding new technological solutions within a predetermined pool of knowledge.

${ }^{15}$ Cockburn, Henderson and Stern (1999) have shown the long lasting influence of “initial conditions' (e.g. prior involvement in scientific activities) to explain firms' regular adoption of science in the pharmaceutical industry. They show that firms that were engaged in science since the beginning of the sample period are the ones who are also the most engaged today in adopting science for drug discovery.

${ }^{16}$ As shown by Zucker et al (2001), the degree to which the scientific literature can produce such strong apparent knowledge capture by firms depends on: a) the characteristics of tacit, complex knowledge that lead to natural excludability (and market exclusion), and b) selection by firms of discoveries for which the degree of knowledge capture is likely to offset sunk costs incurred in making the scientific discovery a commercial innovation.
} 
knowledge is embodied in individual discovering scientists. However, while the figures suggest that university-industry collaboration are widely expanding, the rate of failure or dispute in this kind of agreements remains important. Industry-university links are subject to tensions regarding intellectual property, access and dissemination strategy of knowledge, and others, inhibiting the chances to successfully translate scientific information into new products (Jansen and Thursby, 2001; Thursby and Thursby, 2002; Hall et al, 2001; Poyago-Theotoky et al, 2002). ${ }^{17}$

\subsection{Empirical evidence on effects from science links}

Mostly focused at the firm-level of analysis, the empirical literature has previously assessed the role of scientific-connections, notably partnerships with university researchers, on firm performance (e.g. Audretsch and Stephan, 1996; Zucker et al 1998; Cockburn and Henderson, 1998). Using university collaboration as a scientific-link, these papers coincide in the boosting or complementary effect of cooperation on internal R\&D (Adams et al, 2000), innovation productivity and sales (Belderbos et al, 2005). ${ }^{18}$ While they provide little explanation about the process through which science affects private innovation, the studies relying on the patent production function have found that science involvement and ties with academic star scientists-, can lead to more technology (Henderson and Cockburn, 1996; Zucker et al, 2002; Cockburn and Henderson, 1998); more "important" patents: i.e. international patents (Henderson and Cockburn, 1994); and higher average of quality adjusted patenting (Zucker and Darby, 2001; Zucker et al, 2002).

The work by Cockburn and Henderson (1998) has shown that not only absorption capacity (Cohen and Levinthal, 1989; Kamien and Zang, 2000) in basic research matters but also direct involvement into science. Using data on co-authorship of scientific papers for a sample of pharmaceutical firms, they show that firms connected to science show a higher performance in drug discovery and that this connectedness is closely related to the number of star scientists

\footnotetext{
${ }^{17}$ For instance, in a survey based study on 38 Advanced Technology Projects (ATP), Hall et al (2001) found that projects with university involvement tend to be in areas involving "new" science and therefore experience more difficulty and delay but also are more likely not to be aborted prematurely. In a sample of 62 U.S, university licensing officers, Jensen and Thursby (2001) find that over $75 \%$ of the inventions licensed by these universities were in a very early, or embryonic stage. Further, $71 \%$ of the inventions licensed required cooperation between the professor and the licensing firm in order to commercialize a product successfully (see Agrawal, 2001).

${ }^{18}$ Lööf and Broström, (2004) have found complementarities between internal R\&D and collaboration with universities: the average R\&D firm that cooperate on innovation with universities spend more money on R\&D and has a larger propensity to apply for patents compared to an almost identical R\&D firm which has no such collaboration.
} 
employed by the firm. ${ }^{19}$ Zucker et al (1998) and Darby and Zucker (2001; 2002) found that location of top star scientists predicts firm entry into biotechnology (by new and existing firms) both in the United States and Japan, while Darby and Zucker (2005) recently provided evidence that firms enter nanotechnology where and when scientists are publishing breakthrough academic articles. ${ }^{20}$ For biotechnology in Japan, Darby and Zucker (2001) show that collaborations between particular university star scientists and firms had a large positive impact on firm research productivity, increasing the average firm's biotech patents by 34 percent, products in development by 27 percent, and products on the market by 8 percent as of 1989-1990.

Turning to the evaluation of scientific links at the level of inventions or patents, the little research that exists on this, only offers a partial explanation. In a sample of 83 pharmaceutical and biotechnology firms, Markiewicz (2004) shows that absorption capacity (R\&D intensity and publications) and co-publishing with universities alter the innovation process: both are associated with more exploitation of published scientific research (citations to non patent literature), shorter lag times between existing knowledge and new firm inventions. Mariani (2003) shows that the R\&D intensity and technological specialization of firms (jointly with geographically localized spillovers), matter for the technological impact (forward citation) of biotech and chemical patents. $^{21}$

Regarding the empirical evidence on the contribution of science-linkage (scientific non patent reference) to patent quality, the literature is more inconclusive. One would expect that patents relying on more fundamental knowledge would be more original and more likely to influence different technologies. This argument has found some support in previous studies on university patents (Henderson et al, 1999; Mowery and Ziedonis, 2002; 2002). ${ }^{22}$ Nevertheless, the works that have evaluated on firm patents the determinants of patent value provide more mixed results. Research by Harhoff et al (2003), Fleming and Sorenson (2004), Sorenson and Fleming (2004) or Markus and Reitzig (2003) show divergent results respect to the

\footnotetext{
${ }^{19}$ Differences in the effectiveness with which a firm is accessing the upstream pool of knowledge correspond to differences in the research productivity of firms of as much as $30 \%$.

${ }^{20}$ Furthermore, they report a similar pattern previously reported in biotech: breakthroughs in nanoscale science and engineering appear frequently to be transferred to industrial application with the active participation of discovering academic scientists.

${ }^{21}$ Further, firms' characteristics appear as the most significant drivers of patent quality for chemical patents.

${ }^{22}$ Mowery and Ziedonis (2002) and Sampat, Mowery and Ziedonis (2003) have revised Hendersons' et al (1998) work and found university patents to consistently receive more citations than non-university patents; which confirms the higher quality and broadness of academic inventions.
} 
contribution of non patent references to patent quality. Harhoff et al (2003) found that NPRs are informative about the technological (forward citation) and economic value (patent opposition) of pharmaceutical and chemical patents, but not in other technical fields. ${ }^{23}$ In a study of US patents, Fleming and Sorenson (2004) show that having a "scientific" reference matters for technological impact of patents but that the benefits of using science depend upon the difficulty of the inventive problem being addressed: science only appears as beneficial when researchers work with highly interdependent -or coupled- knowledge pieces -which makes probability of discovery more uncertain.

\section{Empirical Strategy and Variables}

\subsection{Variables for patent quality and science links}

Our purpose in this paper is to evaluate the value of science linkages (invention and firm level) to the quality of patents. In particular, we want to know first whether patents citing science have a stronger technological impact, and are therefore more frequently cited. Second, we want to asses to what extent the attributes of the firm, i.e. the scientific orientation of the firm, contribute to explain the technological impact of inventions (patents). Following past studies on patent quality (e.g. Henderson et al, 1998; Harhoff et al, 1999; Reitzig, 2002; 2003), we use as our dependent variable the number of forward citations received for each patent since the year of application (EPO-OECD, 2005). Our data on forward citation is available up to 2003 and it concerns all citations received from other European Patents and European patents with PCT equivalent. ${ }^{24}$ Previous research has shown that the number of citations a patent receives is associated with its technological importance (Scherer et al, 1999) and social value (Trajtenberg, 1990) and correlated to the renewal of patents, the estimated economic value of

\footnotetext{
${ }^{23}$ In a study of European polymer patent opposition, Reitzig (2002) did not find significant differences between patents reporting non patent references and those not reporting, to explain patent opposition likelihood; a similar finding is reported by Harhoff and Reitzig (2002) for a sample of biotechnology and pharmaceutical patents. However, an important shortcoming of these works is that they do not distinguish whether these non patent references concern scientific publications or not.

${ }^{24}$ Our forward citations measures are built based on the publication date of the patent application. This data comes from the EPO-OECD Patent Citation Database (OECD, 2005). Because our last grant date is 2001, the maximum number of years that our patents can be cited is 6 years (1998-2003) and the minimum is 3 (2001-2003). We take into account citations received during the same year of publication. Our measure of forward citation is the total count of forward citation made by other European patents plus citations made by European patents with WIPO equivalents, for which the international search report is published by the World Patent Office. See Collin et al (2005).
} 
inventions and patent opposition (Lanjouw and Schankerman, 1999; Harhoff et al, 1999).

In addition to the count of forward citations, we also analyze the effects of science linkages on nature of forward citations received. We calculate the generality index of patents across different patent classes and the geographical scope of the citations received. The indicator for generality is build as a Herfhindal index (Jaffe et al, 1997; Hall et al, 2001): Generality $=1-\sum_{i}^{n i} s_{i j}{ }^{2}$, where $s_{i j}$ denotes the percentage of citations received by patent $i$ that belong to patent class $j$, out of $n_{i}$ patent classes ${ }^{25}$. This measure has been used in previous studies as indicative of the impact of a patent, a high generality score suggesting that the patent presumably had a widespread impact, in that it influenced subsequent innovations in a variety of fields (Hall et al, 2001). The index of geographical impact is built in a similar way (1Herfhindhal index of geographical concentration). Both measures are adjusted by the number of groups reported (Hall et al, 2001). To measure the role of science on patent quality, we consider the effect of the patent having a citation to a scientific publication (invention science linkage) and the effect of the firm's linkages to science, as measured by its participation in open science and cooperation with universities (firm's scientific linkage) .

- The invention science-linkage. A patent linkage to science is defined as a dummy variable indicating whether the patent cites at least one NPR considered as a "scientific' publication (found in the ISI-Web of Science). The institutional features of the patent system validate the appearance of citations to science and technology in patents. In order to be patentable, a patent eligible invention must be shown to be both novel and non-obvious. To assess whether an invention disclosed in a patent application satisfies these requirements, a patent examiner reviews the prior art i.e. the search for state of- the-art technical and/or scientific literature, embodied in references to other patents and printed publications. The cited references both -patent and non patent-, define therefore the claims of the patent, its specific uses and applications, methods and procedures, etc. ${ }^{26}$

\footnotetext{
${ }^{25}$ If a patent is cited by subsequent patents that belong to a wide range of fields the measure will be high (close to one), whereas if most citations are concentrated in a few fields it will be low (close to zero).

${ }^{26}$ Though examiners are officially responsible for constructing the list of prior art references against which patentability is judged, they rely in part on applicant disclosure of the prior art submitted with the patent application, on Information Disclosure Statements. The Non patent references (NPR) include scientific articles, technical papers, conference proceedings, textbooks, disclosure bulletins, abstracting services.
} 
While there is strong discussion about the validity of NPR as a 'causal' and 'direct' link to science in patented technology (Tijssen et al, 2000; Tijssen, 2002; Meyer, 2000), there is some recognition of their use as indicators of interplay between science-technology (see Schmoch, 1997; Meyer, 2000). Past research has shown that the average level of non patent references is an appropriate proxy for quantifying the relationship of a technology field to a scientific domain (Van Looy et al, 2004; Callaert et al, 2004). ${ }^{27}$ Researchers have argued however, that NPR should be treated with caution (Tijssen, 2002; Meyer, 2000a, 2000b) as they hardly represent a unidirectional direct link to science. ${ }^{28}$ Others consider (e.g. Jaffe et al., 2000) patent and non patent citations as a "noisy signal" of knowledge flows, with examiners adding much of the noise. ${ }^{29}$ As NPR and patent references are issued from the examiner revision of the prior art, citations rarely reflect or coincide with the science used by inventors (Tijssen, 2002). This is basically the case in the European Patent system where patent applicants are not required to submit descriptions of the state of the art considered relevant to the patentability of the invention, contrary to the American counterpart ('duty of candour' doctrine). ${ }^{30}$

- Firm's scientific linkages (the indirect ISL). These are defined through various connections of the patenting firm with science, but are not necessarily directly related to the focal patent:

i) The cumulated number of scientific publications (found in the ISI Web of Knowledge) by the firm (with publication dates 1990-1995). We also include a dummy indicating whether the firm has been engaged into publication activity: takes the value of 1 if the firm published at least one article up to the year in which the observed patent was filed (application date).

ii) A dummy indicating whether the firm has been engaged into formal cooperation in

\footnotetext{
27 At the industry and country-level, the average intensity of science linkage in patents has been associated to higher national technological productivity, notably in science-intensive fields (Van Looy et al, 2003).

28 Some NPR may reflect cases where technology is actually leading science, or refer to instances of reciprocal relationships where both knowledge generation processes are intertwined.

${ }^{29}$ Harhoff et al. (2003) advance the idea that inserted references by the examiner are frequently a response to a broader patent scope envisaged by the applicant. Using survey based evidence from Dutch inventors, Tijssen (2002) finds that the presence of non patent citations on patents is not related to the science dependence of an invention itself as reported by the inventors themselves. In addition, no correlation is found between an indicator of science-intensity of the firm and the science-linkage of patents.

30 Other limitations refer to the bias imposed by the examiners' individual search strategy and cutting edge technologies with no prior published scientific art (Sampat, 2005). The latter feature would imply that some patents without -scientific- non patent references represent in fact very novel knowledge and cover new technologies. Further, the intensity of citation to the scientific literature may be specific to examiners' characteristics (e.g. teams of junior-senior examiners do appear to identify larger shares of prior art, ibid). Lastly, the outcome of a patent examiners' search is also influenced by external factors such as the availability and treatment of the information (on line access and electronic bibliographic search tools, see Sampat, 2005).
} 
R\&D with universities and governmental research centers. ${ }^{31}$

iii) A dummy indicating whether the firm considers public information a very important source for innovation (firms scoring " 3 " of a scale of three for "using" scientific information being very important). ${ }^{32}$

Data on publications is collected from the ISI-Web of Knowledge database. Data on firms' research strategies (e.g. engagement in research collaboration with universities and research centers and importance of public information for innovation) come from the Belgian Third Community Innovation Survey (1998-2000).

\subsection{Hypotheses}

Being aware of the noise around the use of citations to scientific references in patents, our first research question examines whether patents citing scientific publications are different in nature and scope of technological impact. As the invention they cover has a precedent or basis in the prior scientific art, these patents -like academic patents-, are more likely to cover broader inventions; and receiving therefore more citations in total but notably across different technologies and perhaps from broader geographic areas. ${ }^{33}$ Further, as patent citations have been correlated to commercialization and acquisition of new technologies, a broader scope of forward citation across technologies and countries can be interpreted as bigger opportunities for market commercialization of patents (e.g. Sorenson and Fleming, 2004). ${ }^{34}$

Our second research question stresses whether the technological impact of patents can be explained by firm specific science linkages. Controlling for firm size, we argue that firms engaged into science (as measured by their scientific publication profile) and being involved in technology patenting, build up environments beneficial for developing inventions with high

\footnotetext{
31 Although this variable corresponds to activities reported during 1998-2001, we assume that firm's strategies in research, i.e. collaboration with universities and public research centers do not change radically in the previous 4 years at the last year surveyed: 1998 (1995-1997).

${ }_{32}$ We have defined those firms "using" open science information as those declaring a three points score in the survey (the rank is $0-3,3$ being very important).

${ }^{33}$ Recall however that patents can be viewed as constituting an option for firms when the market scope for such invention is not yet well established at the moment of discovery (or patent application). If the market potential is not realized ex post, those basic patents will not be renewed later and no longer cited.

${ }^{34}$ In their study of forward and backward patent citations for a sample of European patents belonging to CISFrench firms, Duguet and McGarvie (2004) show that forward citation from countries other than France is positively related to French firms' dissemination of knowledge through contract R\&D and equipment sales.
} 
technological impact. Because they follow fundamental knowledge and are able to decode scientific information, these firms are more likely to transfer advances in basic research into potential high impact industrial applications. As shown by Cockburn and Henderson (1998) among others, firms' closeness to science matters to produce high quality patents. We expect therefore a significant "firm individual" effect in the production of quality patents. We also expect patents from scientific firms -independently from the invention-science linkage-, to be broader in generality and geographical scope.

Our third hypothesis concerns the use of science and the nature of the firm. We argue that "scientific firms" engaged into publications are more able and efficient in using open science; and might therefore be more competent to develop higher quality inventions associated to the cited scientific NPR. Therefore, once controlling for the invention-specific and firm specific linkage, we still assume a positive impact of the "scientific firm" dummy; which would imply that patents from scientific firms and having a linkage to science are superior in terms of technological impact to similar patents by firms not involved in science.

Finally, we extend the analysis of patent quality determinants by including a second firm-level linkage to "scientific" communities. We include a dummy variable indicating whether the firm has been engaged into R\&D cooperation with universities. Previous studies have shown that having formal links to universities through cooperative agreements allow firms to better absorb tacit and complex knowledge underlying scientific research thereby increasing the productivity of internal R\&D. We want to test whether cooperation status adds any explanatory power to the quality of patent, once controlled for the scientific-involvement status of the firm through its publications status. We also evaluate the interaction between cooperation status and the scientific NPR reference.

\subsection{Control Variables}

Following the literature on patent quality using forward citations, we need to control for intrinsic attributes of the patent (and technology) that may lead to a higher expected count of forward citations. We include in our model the following variables: 
$>\quad$ Patent citations made: Patent and non patent citations, determine the legal boundaries of the property rights to an invention (Jaffe et al, 1993). ${ }^{35}$ The number of backward citations of a patent reflects the extent of technology dependence but also signals strategies to avoid patent infringement. Some have argued that this is an indicator of cumulativeness of the patent (Reitzig, 2002). ${ }^{36}$ However, the empirical evidence tends to confirm a rather positive impact of patent citations made on forward citation and patent opposition likelihood (e.g. Harhorff et al, 2003; Reitzig, 2002).

Backward citation lag: The citation lag (backward patent citations) is a measure of the time necessary for a firm to assimilate prior technological information and to undertake its inventions. The shorter is this time, the faster the focal patent has been built respect to the cited patent (Fabrizio, 2004; Nagaoka, 2005). We measure this variable as the time (years) between the publication of the cited patent application (in general, a patent cannot be cited before it is published) and the publication date of the referencing search report (OECD-EP Patent Citation Database, 2005).

Patent scope (no. of classes and sub-classes): Following Lerner (1994), we measure patent scope as a count of the number of international patent classes into which the EPO assigns a patent. Research has shown that the scope of a patent may be an important determinant of the efficacy of patent protection (extent of monopoly power) and consequently, of economic value (see, e.g. Scotchmer, 1991). We employ two sets of patent scope indices: one at the 4 IPC digit level and one at the 8 digit IPC level. As explained by Lerner (1994), the more general the research content of the patent (the broader the scope), the higher the probability to be cited by patents in different technology classes. ${ }^{37}$

$>$ Family size: We use the number of countries where patent protection has been sought within the EPO system for our focal patent. Putnam (1996) has shown that the number of jurisdictions in which patent protection is sought for a particular invention is likely to be

\footnotetext{
${ }^{35}$ Patent citations indicate the patent office assignment that a particular invention builds upon the cited knowledge and that protection over this patent may not infringe the technological domains of the cited patents.

${ }^{36}$ Fleming and Sorenson (2004) include the number of prior patent citations as a control for the degree of 'local search'. They argue that patent citations may also capture idiosyncratic differences in citation propensity that technology class controls miss.

${ }^{37}$ We also include a dummy for patents which only cover one IPC classification (8 digit level) to capture any systematic difference between these inventions and those covering multiple subclasses (Fleming and Sorenson, 2004).
} 
correlated with the value of the invention and thus with the value of any single national patent right. $^{38}$

Inventors' Patenting Experience: this variable is measured as the number of patents filed individually by each member of the team in the past (by the same or different assignee), before the date of the focal patent application. It is assumed that inventors that have previously and successfully searched for specific technological problems will more likely to develop more important patents than inventors without any experience (Latham and Le Bas, 2003; Arora et al, 2005). ${ }^{39}$

Past research has shown that the use of science and the science-linkage in patents differs dramatically across technology classes. ${ }^{40} \mathrm{We}$ control for this pattern by including the average intensity of scientific references (relative to the number of non patent references) by technology class. Moreover, the propensity to cite other patents differs dramatically across technology fields. ${ }^{41}$ We control for permanent differences across industries in expected forward citation by including dummies for 5 broad technology classes (IPC Fraunhofer). ${ }^{42}$

\subsection{Methods and Data}

We assume that the process of forward citations follows a Poisson distribution (Hausman et al, 1984), where citation is an event with relatively small probability of success:

$$
\operatorname{Pr}\left(y_{i}=y\right)=\frac{e^{-\lambda_{i}} \lambda_{i}^{y_{i}}}{y_{i} !}
$$

\footnotetext{
${ }^{38}$ Scherer et al (1999) have shown that (international) family size and observed outcomes of opposition cases contribute to an approximation of the patent right's value both in terms of economic value (perceived selling price of the patent) and forward citation.

${ }^{39}$ Recent work by Latham et al (2003) shows that that there is a direct, positive relationship between the involvement of a prolific (or foreign) inventor and the value of the new knowledge produced (forward citation).

${ }^{40}$ The pharmaceutical and chemical, particularly the biotechnology classes, followed by information technologies are amongst the principal classes reporting scientific publications within their non patent references.

${ }^{41}$ The degree of dependence of past technology obligates the patentee to declare of the possible connections with existing patents in order to avoid litigation; technologies such as semiconductors show consequently higher backward citation intensity. The citation propensity over time also differs across technological areas. Citations in Computers and Communications, come the fastest, followed by Electric and electronics (E\&E), Drugs and Medical technologies.

${ }^{42}$ As illustrated by Hall et al (2001) in the USPTO patents, in general, the traditional technological fields cite more and are cited less, whereas the emerging fields of Computers \& Communication (C\&C) technologies and Drugs \& Medical (D\&M) technologies are cited much more but are in between in terms of citations made.
} 
The mean value $\lambda_{i}$ is parameterized by $x_{i}$; the vector of patent and firm attributes; and the coefficient vector $\beta: \lambda_{i}=\exp \left(x_{i}^{\prime} \beta\right) . Y_{i}$ represents the number of forward citations received by patent $i$ (up to year 2003) after the publication of the patent application. There are two issues that restrain the use of the Poisson model when dealing with skewed distributed count data.

First, the Poisson process assumes equi-dispersion, the mean and variance of parameters $\lambda_{i}$ are restricted to be equal, which is not frequently the case. Estimates of a Poisson model for overdispersed data are unbiased, but inefficient with standard errors biased downward (Cameron and Trivedi 1998). The Negative Binomial model (Hausman et al ; 1984$)^{43}$ allows for overdispersion and heterogeneity between subjects by including a unobserved (crosssectional) specific effect $u_{i}$ into the $\lambda_{i}$ so that :

$\lambda_{i}=\exp \left(x_{i}^{\prime} \lambda+u_{i}\right)$

It is assumed that $u_{i}$ is distributed gamma, then the integration leads to the negative binomial model and the unconditional distribution for $y_{i}$ can be expressed as:

$\operatorname{Pr}\left(y_{i}=y \mid x_{i}\right)=\frac{\Gamma\left(\alpha^{-1}+y_{i}\right)^{y_{i}}}{\Gamma\left(y_{i}+1\right) \Gamma\left(\alpha^{-1}\right)} r_{i}^{y_{i}}\left(1-r_{i}\right)^{\alpha-1}$

Where $r i=\frac{\lambda_{i}}{\lambda_{i}+\alpha^{-1}}$. Equation (4) is the form of the negative binomial distribution with mean $\lambda_{i}$ and variance $\lambda_{i}\left(1+\alpha \lambda_{i}\right)$ for $\alpha>0$. The likelihood ratio test for over-dispersion examines the null hypothesis of $\alpha=0 .{ }^{44}$

A second problem that arises is the over-dispersion of zeros in the data. The negative binomial model assumes a same probability process for having a zero than any other discrete value. Zero-inflated models (Zero Inflated Poisson; ZIP ; and Zero Inflated Negative Binomial ; ZINB) handle overdispersion by changing the mean structure to explicitly model the production of zero counts (Long, 1997). The zero inflated models deal with two sources of over-dispersion by portioning the observed variable into a qualitative and quantitative part. The

\footnotetext{
${ }^{43}$ Both Long (1997) and Cameron and Trivedi (1998) note that the unobserved heterogeneity that can cause overdispersion can also cause there to be "excess zeros". In fact, Cameron and Trivedi (1998) review related work by other authors that shows that for certain mixture models, the heterogeneity that gives rise to the overdispersion will always raise the proportion of zeros.

${ }^{44}$ The LR statistic follows the Chi-squared distribution with one degree of freedom. If the null hypothesis is rejected, negative binomial is preferred to the Poisson regression.
} 
ZINB model allows for "excess of zeros" in count models under the assumption that the population is characterized by two regimes, one where members always have zero counts, and one where members have zero or positive counts (Long 1997).

The likelihood of being in either regime is estimated using a logit specification, while the counts in the second regime are estimated using a negative binomial specification. ${ }^{45}$ The probability of zero forward citation $\operatorname{Pr}\left(z_{i}=0 \mid x_{i}\right)$ given covariates $\mathrm{x}$, can be modeled as a logit distribution:

$$
\operatorname{Pr}\left(z_{i}=0 \mid x_{i}\right)=F\left(\gamma^{\prime} X i\right)=\frac{e^{\gamma^{\prime} x}}{1+e^{\gamma^{\prime} x_{i}}}
$$

Then, we can write the unconditional probability of the count of forward citations as:

$$
\begin{aligned}
& \operatorname{Pr}\left(y_{i}=y \mid x_{i}, X_{i}\right)=P\left(z_{i}=0 \mid X_{i}\right)+P\left(z_{i}=1 \mid X_{i}\right) P\left(Y_{i}=y_{i} \mid x_{i}, z_{i}=1\right) \text { or }: \\
& \operatorname{Pr}\left(y_{i}=y \mid x_{i}, X_{i}\right)=F\left(\gamma^{\prime} X_{i}\right)-F\left(\gamma^{\prime} X_{i}\right) P\left(Y_{i}=y_{i} \mid x_{i}\right)+P\left(Y_{i}=y_{i} \mid x_{i}\right)
\end{aligned}
$$

This expression gives the ZINB that we will estimate. In our model the set of covariates $X_{i}$ (in the logit model) and $x_{i}$ (in the count model) are the same; as there is no theoretical framework defining a different set of determinants for the zero citation model and the expected count of forward citations. The Poisson model and ZIP, and NBRM and ZINB cannot, however, be tested by this likelihood ratio, since they are not nested respectively. The Voung's statistic compares these non-nested models. ${ }^{46}$

\subsection{Descriptive statistics}

Table 1 reports the summary statistics of our sample. After restricting our sample of patents with grant dates 1995-2001, in order to have at least three years for forward citation for the patents in 2001, we ended with a total of 1186 patents for a sample of 79 firms. The average forward citations for these Flemish patents is 1.08 citations coming from other European patents (and EPO patents with WIPO equivalents); and 0.67 citations coming only from

\footnotetext{
${ }^{45}$ See Long (1997) Chapter 8 and Greene (1997) for a discussion.

${ }^{46}$ If the Vuong test is greater than 1.96, the ZIP or ZINB is favored. If the test is less than -1.96 , the PRM or NBRM is preferred (Long, 1997). The Vuong statistic is as calculated as: $m_{i}=L N\left[\frac{f_{1}\left(y_{i} \mid X_{i}\right)}{f_{2}\left(y_{i} \mid X_{i}\right)}\right]$

where $f_{1}\left(y_{i} \mid X_{i}\right)$ and $f_{2}\left(y_{i} \mid X_{i}\right)$ are the probability density functions of the ZINB and ZIP respectively. In our case, the Vuong test yield a value of 5.59 with $(\operatorname{Pr}>Z=00)$ justifying our choice of the ZINB over ZIP.
} 
European counterparts. The unconditional standard deviation for the two measures of forward citations is higher than the mean suggesting over-dispersion of data. Table 2 display the distribution of patent science linkages across technology classes. The technology reporting the highest percentage of citations to science is, not surprisingly, chemistry and pharmaceuticals followed by electrical engineering. Process engineering and special equipment report however the highest number of firms having scientific NPR in their patents. This technology also reports a higher number of firms being involved in scientific publication. Table 3 displays the number of patents by firm level science-linkage. Patents from scientific firms represent in total $64.50 \%$ of total patents. While patents from firms that cooperate with universities and public research institutions is $82 \%$. A similar high percentage of patents $(62 \%)$ belongs to firms that consider public sources of information (journals, proceedings; etc.) as a very important source for innovation.

Table 4 displays t-student tests on the comparison of means for some variables of our interest. We want to know whether the characteristics of patents (generality, number of IPC classes, geographical dispersion, backward citation time) and their impact on subsequent technology development (forward citations) differ between patents with and without scientific linkages (both at the invention and at the firm level). In panel A and B, we compare patents that did not have any citation to science to patents having at least one scientific NPR. There are no significant differences between the two groups in terms of forward patent citations. However, there are significant differences in terms of scope (number of sub-sub classes IPC-4) and generality, with patents with scientific NPR displaying a larger scope and generality.

Panel B and C compare patents between firms involved in scientific publication and the rest of firms (patents). Scientific firms have significantly more forward citations (both total and relative (i.e. compared to the average in the same IPC class)), are broader in terms of no. of IPC classes, and report a higher geographical impact. The panels D to G split firms' patents into patents -without and with- a linkage to science (scientific NPR) for each group of firms. The panel D-E displays the patents for the group of firms with publications. It turns out that the patents having a scientific NPR are only different in terms of generality (higher). Looking at the panel F-G, in the group of patents from firms not engaged into science there are no significant differences between NPR and non-NPR patents. The same holds for the panel G-E which compares patents with NPR for the two types of firms. 
However, the panel F-D comparing patents without NPR across the two types of firms, finds significant differences. Non-NPR Patents from firms that are involved in science report higher forward citation and intensity, they cover a large number of IPC classes, and have a higher geographical impact but are not necessarily more general than non-NPR patents from firms' not engaged into science. These results provide some first evidence, although partial, about the importance of firm specific linkages rather than invention specific.

\section{Econometric Results}

\subsection{The impact of science linkages on forward citation}

Table 5 displays the step by step regressions using negative binomial and zero-inflated negative binomial (ZINB) count regression. The goodness of the fit across the different specifications is reported at the bottom in addition to the Vuong tests discriminating between ZINB and negative binomial, and ZINB and zero inflated poisson. We include a set of 4 technology dummies (the reference being Mechanical and engineering technologies), and two period dummies in all models. Robust standard errors are reported and adjusted for intra-group correlation of errors (clustered by firm). The ZINB specifications split into the count model (conditional on having a positive and superior to zero forward citation) and logit model (probability of zero forward citation). ${ }^{47}$

Before discussing the variables of interest, we first briefly discuss the fitness of the different estimation methods. The Negative Binomial model is preferred over the Poisson model as confirmed by the test of over-dispersion. These first estimations corroborate the previous findings reported in the t-tests comparison of means. According to the estimates of the negative binomial, patents having a citation to a scientific publication are not significantly different from other patents in the expected technological impact; they do not receive more forward citations. The convergence of the model improves slightly with the inclusion of the scientificfirm dummy. Similar results are corroborated in the with the ZINB model. The Vuong test corroborates the superiority of the Zero Inflated Negative Binomial over the standard negative

\footnotetext{
${ }^{47}$ Logit coefficients can be interpreted like the normal logistic coefficients. In the logit part of the model, coefficient with a negative sign mean that changes in the related variable are inversely related to the likelihood of belonging to the zero citation group. In principle, the coefficients in the discrete part of the model (logit of zero citation) are expected to be the opposite of the expressed in the count model.
} 
model (5.99 at 1\%). ${ }^{48}$ Further, the likelihood ratio test comparing the ZINB to the ZIP suggests the preference of the former. Thus, two sources of dispersions exist in our data; one arising from the high number of zeros, and a second one coming from the between subject heterogeneity. ${ }^{49}$

Three main findings arise from the ZINB regressions. First, contrary to our expectations, but confirming our findings on comparison of means, patents citing science seem not to have a higher citation impact. The science linkage reflected in the citation to scientific publication status is never significant across the different models. There is no relationship between citing a scientific NPR and the expected count of forward citations even when correcting for overdispersion and heterogeneity. Second, the size of the firm (no. of employees) appears not to be relevant to explain patent quality (columns 5 and 6) in the count part of the model but it is significant in the logit $\operatorname{model}^{50}$ : firm size is negatively and significantly associated to the likelihood of not receiving a forward citation at all. ${ }^{51}$ Recall that some theory (Schumpeter; 1945); argues that big firms might be more capable of producing high quality technology, because of scale economies; advantages in accessing upfront knowledge in the market. And third, the dummy identifying scientific firms (i.e. those engaged in scientific publication) appears as positive (column 7), which confirms the hypothesis of a firm' specific effect for patent quality. Conditional on receiving a citation, the estimate of column 7 suggests that being a firm engaged in open science increases the expected count of forward citation by $30 \%$. Expressed in factor changes, being a scientific firm increases the expected rate of forward citation by a factor of $1.3 .^{52}$ The scientific firm dummy variable is however not significant in explaining the probability of receiving forward citations.

\footnotetext{
${ }^{48}$ The null hypothesis of the dispersion parameter (alfa) equal to zero is rejected at $1 \%$ (chi2(1)=99.72); which confirms the overdispersion of our dependent variable; and justifies the adoption of negative binomial model over a poisson specification.

${ }^{49}$ As there is not underlying theoretical model distinguishing this probability from the expected count of citations we cannot assume an equivalent direct economic interpretation as in the count model. The use of the ZINB model attempts to correct for part of the "noise" characterizing the skewed distribution of citations associated to the over-dispersion of data and the intrinsic heterogeneity; as well as the excess of zeros.

${ }^{50} \mathrm{We}$ also included information on firm R\&D expenditures from the CIS-survey, but the data on this variable are very noisy and do not generate robust results.

${ }^{51}$ This result differs from the one reported by Gambardella et al (2005) on a sample (survey based) study on EPO patents for France, UK, Germany, Italy, Netherlands and Spain. They found that small and medium firms report higher economic value as conceived by the first or second inventor.

52 A log-likelihood ratio comparing the unrestricted versus restricted model gives a chi2 $(1)=6.48$ with Prob $>$ chi $2=0.032$, while a Wald test on the significance of the dummy gives chi2 $2(1)=5.86$ with $\operatorname{Prob}>\operatorname{chi} 2=0.052$
} 
With respect to the other control variables, our results show that the higher the number of backward patent citations, the larger the probability of not receiving a citation. Thus patents that rely more intensively in previous technologies are of a more cumulative or incremental nature. Further, patents that report a higher backward citation lag between the date of publication and the backward cited patents, are less likely to be found in the zero-citation group. Furthermore, patent quality is negatively associated to patents having a single IPC technology class (4 digit IPC classes); that is, very narrow patents shows a lower expected count of forward citations; although the effect is not significant. The results on the number of jurisdictions covered in the European community (EPO) seem to indicate that inventions that are filed internationally (although at the regional level) are more likely to cover quality patents. In addition, patent quality appears positively associated to the amount of past patenting by inventors. Experience enables inventors to develop more complex technologies, learn from past research; and improve quality of their research.

We want to elucidate what is behind the higher forward citation reported in patents without NPR in the previous descriptive analysis. The possible explanation for such patterns would be the existence of internal spillovers -knowledge transfers across inventors - that could be the link between patents with and without basic knowledge. Patents without NPR could be inventions having high qualified inventors that have come up with successful technological applications of existing fundamental knowledge. The very first patents with scientific NPR might be too complex or representing technologies at very embryonic stage to already receive a higher citation frequency. We investigate this issue in the Table 6. The columns 1 and 2 report a ZINB model only in the sample of patents without NPR. The scientific-firm dummy appears significant, although with a similar impact as reported in the total sample. This finding suggests that even in the absence of invention-specific science linkages, firms that are formally involved into scientific activities (open science) are capable of producing higher impact patents. It also suggests that the achievement of higher quality inventions by scientific firms follows a process of breaking up technology building on more fundamental innovations (patents with non patent references). The rest of the model display coefficients close to those from the total sample model.

Columns 3 and columns 4 report the ZINB model for the sample of patents in electrical engineering technologies, instruments, chemicals and pharmaceuticals, i.e. those technologies that typically are considered as science-intensive. Contrary to the regressions on the total 
sample, the quality of inventions measured by the count of forward citations in these science intensive industries appears to be largely influenced by individual science linkage: being a firm engaged in open science increases the expected count of forward citation by more of $45 \%$. Expressed in factor changes, being a scientific firm increases the expected rate of forward citation by a factor of 1.46. This finding is in line with the descriptive studies highlighting the preponderant importance (frequency) of science linkages in emerging technology fields (Hicks et al, 2000; Branstteter, 2004; Callaert et al, 2003). The firm-level science linkage however appears as an irrelevant factor of patents' technological impact. We repeat the exercise of restricting the analysis to the sample of patents without NPR now for the science intensive technologies (columns 5 and 6). Again, it turns out that the scientific firm dummy is not longer important to explain technological impact of inventions. Hence, these findings suggest that the firm-level linkages to science matter for patent quality in general, but that they are however less important when the technologies concerned are highly evolving technologies. Likewise, the invention-specific linkage to science seem to matter for more science based technologies where breakthroughs are more frequently of taking place out of firms' laboratories --more likely to emerge at universities and public research centers-. We should take these results however with caution as our sample represents just a small part of the picture of total patenting in these technologies and our universe of firms is rather small.

A last exercise in this section, assessing to evaluate the contribution of ISL in patent quality, consists in testing the other firm-level science linkages reported in the CIS. For purposes of saving space, table 7 displays only the count part of the ZINB models and presents sequentially the different ISL linkages. Column 2 reports the baseline model with the dummy on firms considering public information sources as a very important channel for innovation. The coefficient and its significance are not so much different from the scientific-firm dummy and the tests on the goodness of fit do not change dramatically. This finding validates therefore the use of the CIS variable (use of public information) as a good predictor of involvement in scientific activities by firms. Given our small sample of firms and multicolinearity between these two variables, we are not however successful to isolate the effects of these two variables (column 4) on patent quality. We include the dummy on collaborating firms (with universities and public institutions) in the column 3. Contrarily to previous findings, patents from firms that cooperate in R\&D with universities, do not generate any significant effect neither on the likelihood nor on the count of forward citations. The model in column 5 includes the different 
firm-level ISL. Again, given the limitation of our data the regressions are unsatisfactory to properly assess the individual effects of the different firm-level linkage measures to science.

Lastly, the right part of the table 7 reports interactive terms in order to identify citation premiums related to comparative advantages in the use of science by scientific-oriented firms. None of the interactions appeared as significant drivers of technological impact of patents. ${ }^{53}$

\subsection{The impact of science linkages on the scope of forward citation}

The last part of our empirical analysis evaluates our research questions with respect to the scope of forward citation for patents and the impact of science linkages. Table 8 displays regressions on the generality and geographical index as well as on the speed of forward citations. The Herfindahl indices for generality across technology classes and countries are estimated using Tobit regression (1-2 and 5-6). We have also estimated the probability of receiving a forward citation in a different IPC 4 digit class and the probability of receiving a citation by a foreign country using Probit models (models 3-4 and 7-8 respectively). Regressions on the median forward lag and shortest citation lag are made with Ordinary Least Squares. Marginal effects are reported for the Probit models.

Estimates in the Tobit model (1 and 2) show that patents having at least one citation to scientific publications are indeed broader in scope: patents having a scientific reference have a $28 \%$ larger generality index. Furthermore, NPR patents have a $16 \%$ higher probability of receiving a forward citation in a different IPC-4 technology class (model 3), holding all the other variables constant at their sample means. The dummy variable for scientific firm is not significant to explain neither the generality scope of patents being cited (columns 1 and 2) nor the geographical impact of patents (columns 5 and 6). No additional effect is detected on the interactive terms neither in the generality and geographical dispersion models nor in the Probit models for different IPC class citations. Nevertheless, the estimation of the Probit model (model 8) on the probability of receiving a citation from a foreign country appears to confirm the wider international diffusion of patents when the two indicators of scientific linkages are

\footnotetext{
${ }^{53}$ This result might seem to be in contradiction with most of the past literature at the firm level that has positively evaluated cooperative links with academia on firms' innovation performance (e.g. Darby and Zucker, 2001; Zucker et al, 2002). Recall that the effects we are analyzing here are at the level of the patented invention and therefore not directly comparable with firm level performance evaluations.
} 
included jointly with their interaction term; the effects are however small. Lastly, the ordinary least squares regression on the median citation time and the shortest citation time, reveals that patents from firms with scientific publications report shorter forward citation lag (both in the median and shortest time models); This result confirms the speed of diffusion related to inventions coming from scientific firms.

\section{Conclusions}

This research has attempted to bring new evidence on the contribution of science linkages. In particular, this research has analyzed for a sample of Flemish patents the role of inventionspecific science linkages and firms-closeness to science on the quality of patents, as measured by the number and scope of forward citations. .

Our results are summarized as follows. First, the descriptive and econometric investigations show that references to scientific publications are not relevant to explain forward citation. This finding can be explained by the observation that patents citing science may be uncovering extremely complex and fundamental knowledge that is not easy to diffuse or may be yet far from the market application. However, the citation to science is positively related to the scope of technological impact; both in terms of generality and probability of being cited by a foreign country. Second, we find the invention-specific linkage to science, measured by references in the patent to a scientific publication, to appear only as a significant driver of patent quality in the science based technologies but this result needs still to be verified in a larger sample. And third, firm's closeness to science matters for patent quality: in particular, non-science related patents of firms with firm level scientific linkages are more frequently and more quickly cited than comparable patents of firms without these science linkages. This finding supports the existence of internal spillover within scientific-oriented firms (inventors' collaboration) and suggests an innovation process consisting in achieving high impact technology building on more fundamental innovations (patents with non patent references). In this way, this paper calls for a broader perspective in the evaluation of determinants of patent quality and the study of science linkages and innovation performance.

Before drawing any firm conclusions, the results presented here are suggestive of further research. The Flemish data set is limited in terms of the number of firms active in innovation, 
patents and particularly science links as measured through publications. But the methodology used in this paper, relying on a combination of internationally standardized datasets, can easily be replicated for other countries to check robustness of results on a larger sample of active firms. The small number of firm cases of science linkages in the Flemish data provides nevertheless an opportunity to examine in more detail, the mechanisms in place in these firms to realize intra-firm spillovers. A fruitful avenue for further work is to examine the patterns of self-citations across scientific and non-scientific patents of these firms. But also the pattern of core inventors \& teams across firm patents needs to be brought in the analysis as a likely mechanism for intra-firm spillovers. In any case, the level of inventor-specific science linkages should be integrated with the invention- and firm-specific level to complete the analysis.

\section{References}

Acs, Z. J., Audretsch, D. B. and Feldman, M.P. (1992) Real Effects of Academic Research. American Economic Review, 82, 363-367.

Adams, J. D. (1990). Fundamental stocks of knowledge and productivity growth, Journal of Political Economy, 98, 673-702.

Ahuja G., Katila R, (2004). Where do Resources Come From? The Role of Idiosyncratic Situations. Strategic Management Journal, 25: 887-907.

Arora, A., and Gambardella, A. (1990). Complementarity and External linkages: the strategies of the large firms in Biotechnology, Journal of Industrial Economics, 38, 361-379.

Arrow, K. J. (1962). Economic welfare and the allocation of resources for invention. Richard R. Nelson, ed. The rate and direction of inventive activity, Princeton University Press, Princeton.

Arundel, A. and Geuna, A. (2004).Proximity and the Use of Public Science by Innovative European Firms', Economics of Innovation and New Technology, Vol. 13, pp559-580, 2004.

Audretsch, D.B. and Stephan, RE. (1996) Company-scientist locational links: the case of biotechnology, American Economic Review, 86: 641-652. 
Beath, John and Donald S. Siegel (2002) Universities and Fundamental Research: Reflections on the Growth of University-Industry Partnerships. Oxford Review of Economic Policy, 2002, vol. 18, issue 1, pages 10-21

Branstetter, L. (2004), Exploring the Link Between Academic Science and Industrial innovation, unpublished working paper.

Branstetter, L. and Yoshiaki, Ogura (2005). Is academic science driving a surge in industrial innovation? Evidence from patent citations. NBER working paper 11561, August.

Callaert, Julie, Van Looy, Bart, Verbeek Arnold, Debackere Koenraad, Thijs, B. ( 2004) Traces of prior art: An analysis of non patent references found in documents. KU Leuven, mimeo.

Cameron C, Trivedi P. 1998. The Analysis of Count Data. Cambridge University Press:New York.

Cohen W. M, Levinthal DA. (1990). Absorptive capacity, a new perspective of learning and innovation. Administrative Science Quarterly 35: 128-152

Cohen W. M, Levinthal, DA. (1989). Innovation and learning: the two faces of R\&D. The Economic Journal 99: 569-596.

Cassiman, B. \& R. Veugelers (2002), R\&D Cooperation and Spillovers: some empirical evidence from Belgium, American Economic Review, 92, 4, 1169-1184.

Cockburn, I., Henderson, R. and Stern, S. (1999). The Diffusion of Science-Driven Drug Discovery: Organizational Change in Pharmaceutical Research, NBER document de travail no. 7359, National Bureau of Economic Research, Inc.

Cockburn, Iain and Rebecca Henderson, (1998). The Organization of Research in Drug 38, Discovery, Journal of Industrial Economics, Vol XLVI, No. 2.

Cockburn, Iain, Rebecca Henderson, and Scott Stern (1999), The Diffusion of Science Driven Drug Discovery: Organizational Change in Pharmaceutical Research, NBER Working Paper No. 7359.

Cohen, Wesley M.; Nelson, Richard; Walsh, R. John P. (2002). Links and Impacts: The Influence of Public Research on Industrial R\&D, Management Science, Vol. 48, No. 1, January 2002 pp. 1-23 
Darby, M. and Lynne, G. Zucker (2005) Grilichesian breakthrougus: Inventions of methods of invention and firm entry in nanotechnology, Annales d'Economie et Statistique, forthcoming.

Darby, M. R. and Lynne, G. Zucker (2002), Going public when you can in biotechnology. NBER working paper, no. 9854.

Darby, M. R., L. G. Zucker (2001). Change or die: The adoption of biotechnology in the Japanese and U.S. pharmaceutical industries. Res. Tech. Innovation, Management, Policy 7: $85-125$.

Duguet Emmanuel \& Megan MacGarvie (2005) How well do patent citations measure flows of technology? Evidence from French innovation surveys, Economics of Innovation and New Technology, Taylor and Francis Journals, vol. 14(5), pages 375-393, July.

Evenson, Robert E., and Yoav Kislev, A Stochastic Model of Applied Research, Journal of Political Economy 84 (April 1976): 265-281.

Fleming, L., and Sorenson, O. (2004) Science as a map in technological search. Strategic Management Journal, 25, pp. 909-9280.

Gambardella, A. (1994). The changing technology of technical change: General and abstract knowledge and the division of innovative labor. Research Policy, 23, 523-532.

Gambardella, A., Harhorff, D., Verspagen, B. (2005). The value of patents. Bocconi University, mimeo.

Greene W H. 2000. Econometric Analysis. Prentice Hall: Upper Saddle River

Hall B. H, Jaffe AD, Trajtenberg M. (2001). Market Value and Patent Citations: A First Look, Economics Department Working Paper E00-277, University of California

Hausman J, Hall BH, Griliches Z. (1984). Econometric models for count data with an application to the patents-R\&D relationship. Econometrica 52(4): 909-938

Guellec, D. and Van Pottelsbergue de la Potterie, B. (2000). Applications, grants and the value of patents, Economic Letters 69 (1).

Guellec, D. and Van Pottelsbergue de la Potterie, B. (2001) The internationalization of technology analysed with patent data, Research Policy, 30 (8), 1256-1266. 
Hall, B. H., Jaffe, A., Trajtenberg, M., (2000). Market Value and Patent Citations: A First Look. NBER, Cambridge, MA, mimeo.

Harhoff, D., Reitzig, M., (2004). Determinants of Opposition Against EPO Patent Grants: The Case of Pharmaceuticals and Biotechnology, International Journal of Industrial Organization, 22/4, 443- 480 .

Harhoff, Dietmar \& Scherer, Frederic M. \& Vopel, Katrin, (2003). Citations, family size, opposition and the value of patent rights, Research Policy, Elsevier, vol. 32(8), pages 13431363.

Harhoff, Dietmar and Narin, Francis, F. M. Scherer and Katrin Vopel (1999). Citation Frequency And The Value of Patented Inventions, The Review of Economics and Statistics, MIT Press, vol. 81(3), pages 511-515

Harhoff, Dietmar and Reitzig, Markus, (2002). Determinants of Opposition Against EPO Patent Grants - The Case of Biotechnology and Pharmaceuticals, CEPR Discussion Papers 3645, C.E.P.R. Discussion Papers

Henderson, R., A. Jaffe, M. Trajtenberg (1998), Universities as a source of commercial technology: A detailed analysis of University patenting, 1965-1988. Review of Economics and Statistics, 65, 119127.

Hicks, D., Breitzman, T., Olivastro, D., Hamilton, K. (2001). The changing composition of innovative activity in the US a portrait based on patent analysis. Research Policy, 30, 2001, 681-703.

Jaffe, A. B., Trajtenberg, M. Henderson, R. (1993). Greographic Localization of knowledge spillovers as evidenced by patent citations. Quaterly Journal of Economics 108, 577-598.

Jaffe, A., (1989), The Real Effects of Academic Research, American Economic Review, 79 (5), pp. $957-70$.

Jensen, Richard, and Marie Thursby (2001). «Proofs and Prototypes for Sale : The Licensing of University Inventions ». American Economic Review, 91(1) : 240-59.

Kim, Jinyoung; Lee, Sangjoon John and Marschke, Gerald (2005). The influence of university research on industrial innovation NBER working Paper 11447, june 2005.

Lanjouw, J. O., Schankerman, M. (1999). The Quality of Ideas: Measuring Innovation with Multiple Indicators. NBER, Boston, MA. 
Latham, W., Gay, L. and C. Le Bas (2003).Collective Knowledge, Prolific Inventors and the Value of Inventions: An Empirical Study of French, German and British Owned U.S. Patents, 1975-1998. University of Delaware, department of Economics. Mimeo.

Lerner, J., (1994). The importance of patent scope: an empirical analysis. RAND Journal of Economics 25 (2), 319-333.

Liebeskind JP, Oliver AL, Zucker L, Brewer M. 1996. Social networks, learning, and flexibility: sourcing scientific knowledge in new biotechnology firms. Organization Science 7(4): 428-442

Mansfield, Edwin (1991). Academic Research and Industrial Innovation. Research Policy, vol. 20(1), pages 1-12Mansfield 1992

Mansfield, E., (1995), Academic Research Underlying Industrial Innovations: Sources, Characteristics, and Financing," The Review of Economics and Statistics 77: 55-65.

Markiewicz, Kira, (2004), Absorptive Capacity and Innovation: Evidence from Pharmaceutical and Biotechnology Firms, working paper, UC-Berkeley.

Meyer, M. (2000). Does science push technology? Patents citing scientific literature. Research Policy 29, 409-434.

Mowery, D. C., B. N. Sampat and Ziedonis, A. A. (2001), Learning to patent: institutional experience, learning, and the characteristics of US university patents after the Bayh-Dole Act, 1981-1992', Management Science 48(1): 73-89.

Nagaoka, Sadao (2005), Patent quality, cumulative innovation and market value: Evidence from Japanese firm level panel data. Hitotsubashi University, mimeo.

Narin, F. and R. P. Rozek (1988) 'Bibliometric Analysis of US Pharmaceutical Industry Research Performance', Research Policy, 17: 139-15.

Narin, F., Hamilton, K., Olivastro, D., (1997). The increasing linkage between US technology and public science. Research Policy 26, pp. 317-330.

Nelson, R. R. (1982). The role of knowledge spillovers in R\&D efficiency. Quaterly Journal of Economics 97, 297-306.

Nesta, L. and Vincent, M. (2005). The dynamics of innovation networks. SPRU Electronic Working Paper Series 114, University of Sussex, SPRU. 
Poyago-Theotoky, J. Beath and D.S. Siegel J. (2002). Universities and fundamental research: reflections on the growth of university-industry partnerships, Oxford Review of Economic Policy, 18 (1), pp. 10-21.

Reitzig, M. (2003), What do patent indicators really measure? A structural test of novelty and inventive step as determinants of patent profitability, LEFIC WP 2003-1.

Reitzig, Markus (2002). Improving Patent Valuation Methods for Management, Validating New Indicators by Understanding Patenting Strategies Lefic Working Paper 2002-09.

Rosenberg, N. (1990). Why do firms do basic research (with their own money)? Research Policy, 19, 165-174.

Sorenson, Olav and Fleming, Lee (2004). Science and the diffusion of knowledge, Research Policy, 33, pp. 1615-1634.

Stern, Scott (1999). Do Scientists Pay to Be Scientists?, NBER Working Papers 7410, National Bureau of Economic Research, Inc.

Thursby J. G. and M.C. Thursby, (2002) Who is selling the Ivory Tower? Sources of growth in university licensing. Management Science, 48, 90-104.

Tijssen, R. (2001). Global and domestic utilization of industrial relevant science: patent citation analysis of science-technology interactions and knowledge flows. Research Policy 30: $35-54$.

Tijssen, R. J. W. (2002). Science dependence of technologies: evidence from inventions and their inventors. Research Policy 31 (2002), 509-526. 6.

Trajtenberg, M. (1990), A penny for your quotes: patent citations and the value of innovation RAND Journal of Economics, 21 (1), 172-187.

Van Looy, Bart; Magerman, Tom; Debackere, Koenraad (2004). Developing technology in the vicinity of science: An examination of the relationship between science intensity and technological productivity within the field of biotechnology. KU Leuven, mimeo.

Veugelers, R. and Cassiman, B. (2005). R\&D Cooperation between firms and universities: Some empirical evidence from Belgian manufacturing. Forthcoming International Journal of Industrial Organization. 
Webb, C., Dernis, H. Harhoff, D. Hois, K. (2005). Analysing European and International Patent Citations: A Set of EPO Patent Database Building Blocks, OECD Science, Technology and Industry Working Papers 2005/9, OECD.

Zucker,. Lynne G.; Darby Michael R \& Armstrong, Jeff S. (2002). Commercializing Knowledge: University Science, Knowledge Capture, and Firm Performance in Biotechnology, Management Science, 48(1), 2002

Zucker, Lynne G and Darby, Michael R, (2001). Capturing Technological Opportunity via Japan's Star Scientists: Evidence from Japanese Firms' Biotech Patents and Products, The Journal of Technology Transfer, Springer, vol. 26(1-2), 37-58.

Zucker, Lynne, Michael Darby, and Michael Brewer (1998), Intellectual Capital and the Birth of U.S. Biotechnology Enterprises, American Economic Review, 88, 290-306.

Zucker, Lynne, M. Torero. (2000). Determinants of embodied technology transfer from stars to firms. Working paper, UCLA Anderson School, Los Angeles, CA. 
Table 1 Descriptive Statistics

\begin{tabular}{|c|c|c|c|c|c|c|}
\hline Variable & Description & Obs & Mean & Std Dv & Min & Max \\
\hline Forward citation (EP-WIPO) & $\begin{array}{l}\text { Total count of citations received by other } \\
\text { European patents and WIPO patents with } \\
\text { European equivalent (up to 2003) }\end{array}$ & 1186 & 1.084317 & 1.957689 & 0 & 19 \\
\hline Generality & $\begin{array}{l}\text { Herfhindhal index (IPC classes) on forward } \\
\text { patents (Jaffe et al, 1998; Hall et al, 2000) }\end{array}$ & 387 & .0961174 & .1933514 & 0 & .72 \\
\hline Forward citation lag & Shortest forward patent citation time (in years) & 518 & 3.067568 & 1.88583 & 0 & 10 \\
\hline Median forward citation lag & Median forward patent citation time (in years) & 518 & 3.488417 & 1.949027 & 0 & 13 \\
\hline Geographical impact & $\begin{array}{l}\text { Degree of international dispersion of forward } \\
\text { patent citations (across foreign countries) }\end{array}$ & 493 & .1842779 & .2517489 & 0 & .8703704 \\
\hline Backward citation time & $\begin{array}{l}\text { Time difference in years between the publication } \\
\text { date of the focal patent and the cited patent } \\
\text { reference } \\
\text { (OECD, 2005) }\end{array}$ & 1114 & 9.720676 & 7.753028 & -2 & 59 \\
\hline Age difference & $\begin{array}{l}\text { Time difference in years respect to the grant date } \\
\text { of the focal patent and the cited patent reference }\end{array}$ & 1186 & .96543 & 1.805192 & -5 & 9 \\
\hline Unique IPC class & $\begin{array}{l}\text { Dummy referring to patents with single IPC } 4 \\
\text { digit class. }\end{array}$ & 1186 & .3583474 & .4797172 & 0 & 1 \\
\hline Family Size (Europe) & $\begin{array}{l}\text { Number of designated states within the } \\
\text { European Community }\end{array}$ & 1186 & 8.123946 & 4.880581 & 2 & 19 \\
\hline No. of Sub classes (IPC 4 digit) & No. of fields (4 digit IPC) covered by the patent & 1186 & 1.230185 & 1.682413 & 0 & 21 \\
\hline Patent Citations made & $\begin{array}{c}\text { Backward patent citations made } \\
\text { (total found in EPO and WIPO search reports) }\end{array}$ & 1186 & 3.953626 & 2.222336 & 0 & 15 \\
\hline Firm size & Number of Employees & 1186 & 7.75601 & 1.349705 & 2.484907 & 8.711114 \\
\hline No. of inventors & Proxy for the cost of the invention: team size & 1185 & 2.556962 & 1.352677 & 1 & 10 \\
\hline Past patenting by inventors & $\begin{array}{l}\text { No. of previous patents (granted) } \\
\text { up to } 1995 \text { by inventors }\end{array}$ & 1186 & 12.49916 & 11.77226 & 1 & 52 \\
\hline Prolific Inventor & $\begin{array}{c}\text { Dummy on inventors having more than } 5 \text { patents } \\
\text { granted in the past }\end{array}$ & 1186 & .6365936 & .4811833 & 0 & 1 \\
\hline SEC1 & Electrical Engineering & 1186 & .118887 & .3237921 & 0 & 1 \\
\hline SEC2 & Instruments & 1186 & .3684654 & .482592 & 0 & 1 \\
\hline SEC3 & Chemistry and pharmaceuticals & 1186 & .118887 & .3237921 & 0 & 1 \\
\hline SEC4 & Process engineering, special equipment & 1186 & .3229342 & .4677951 & 0 & 1 \\
\hline SEC5 & Mechanical engineering, machinery & 1186 & .0708263 & .2566427 & 0 & 1 \\
\hline y1996_y1998 & $\begin{array}{l}\text { Dummy for patent cohort with grant dates 1996- } \\
\qquad 1998\end{array}$ & 1186 & .4232715 & .4942861 & 0 & 1 \\
\hline y1999_y2001 & $\begin{array}{l}\text { Dummy for patent cohort with grant dates 1999- } \\
\qquad 2001\end{array}$ & 1186 & .5767285 & .4942861 & 0 & 1 \\
\hline
\end{tabular}


Table 2: Distribution of Patents and Science-linkages (Invention specific)

\begin{tabular}{|c|c|c|c|c|c|}
\hline Technology Class & Patents & $\begin{array}{l}\text { Patents with Scientific } \\
\text { Non Patent References }\end{array}$ & $\begin{array}{l}\% \text { Patents with } \\
\text { scientific NPR }\end{array}$ & No. of Firms & $\begin{array}{l}\text { No. Firms with } \\
\text { scientific NPR }\end{array}$ \\
\hline Electrical Engineering & 141 & 16 & $11,35 \%$ & 15 & 4 \\
\hline Instruments & 437 & 47 & $10,76 \%$ & 12 & 7 \\
\hline Chemistry and pharmaceuticals & 141 & 32 & $22,70 \%$ & 9 & 3 \\
\hline Process engineering, special equipment & 383 & 31 & $8,09 \%$ & 28 & 9 \\
\hline Mechanical engineering, machinery & 84 & 4 & $4,76 \%$ & 28 & 4 \\
\hline Total & 1186 & 130 & $10,96 \%$ & 92 & 27 \\
\hline
\end{tabular}

Table 3: Distribution of Firm-Level Science Linkages

\begin{tabular}{|c|c|c|c|c|c|c|c|c|c|}
\hline Technology Class & $\begin{array}{c}\text { Scientific } \\
\text { Firms } \\
\text { (publications) }\end{array}$ & $\begin{array}{l}\text { Patents of } \\
\text { scientific } \\
\text { firms }\end{array}$ & $\%$ & $\begin{array}{l}\text { Cooperating } \\
\text { with } \\
\text { universities }\end{array}$ & $\begin{array}{l}\text { Patents of } \\
\text { cooperating } \\
\text { firms }\end{array}$ & $\%$ & $\begin{array}{l}\text { Firms that use } \\
\text { Public } \\
\text { Information }\end{array}$ & $\begin{array}{l}\text { Patents of } \\
\text { firms that use } \\
\text { Public } \\
\text { Information }\end{array}$ & $\%$ \\
\hline Electrical Engineering & 3 & 96 & $68,09 \%$ & 7 & 127 & $90,07 \%$ & 2 & 98 & $69,50 \%$ \\
\hline Instruments & 4 & 291 & $66,59 \%$ & 7 & 395 & $90,39 \%$ & 4 & 407 & $93,14 \%$ \\
\hline Chemistry and pharmaceuticals & 4 & 121 & $85,82 \%$ & 4 & 122 & $86,52 \%$ & 3 & 121 & $85,82 \%$ \\
\hline Process engineering, special equipment & 8 & 221 & $57,70 \%$ & 12 & 296 & $77,28 \%$ & 6 & 211 & $55,09 \%$ \\
\hline Mechanical engineering, machinery & 5 & 36 & $42,86 \%$ & 10 & 32 & $38,10 \%$ & 15 & 15 & $17,86 \%$ \\
\hline Total & 24 & 765 & $64,50 \%$ & 40 & 972 & $81,96 \%$ & 30 & 852 & $71,84 \%$ \\
\hline
\end{tabular}

Note: Firms that use public information (intensively) are those declaring a three points score in the CIS survey (the rank is $0-3,3$ being very important). 
Table 4: Comparison of Means (T-tests)

\begin{tabular}{|c|c|c|c|c|c|c|}
\hline Variable & Obs & Mean & Obs & Mean & $\mathbf{t}$ & $\operatorname{Pr}(\mathrm{T}<\mathrm{t})$ \\
\hline \multicolumn{3}{|c|}{ A. Patents without scientific NPR } & \multicolumn{4}{|c|}{ B. Patents with Scientific NPR } \\
\hline Forward Citation & 1056 & 1,08 & 130 & 1,10 & $-0,078$ & 0,461 \\
\hline Intensity citation & 1056 & 0,61 & 130 & 0,57 & 0,337 & 0,633 \\
\hline generality & 355 & 0,09 & 32 & 0,18 & $-2,14$ & 0,019 \\
\hline No. IPC clases & 1056 & 1,20 & 130 & 1,46 & $-1,585$ & 0,051 \\
\hline Geographic scope & 447 & 0,18 & 46 & 0,23 & $-1,139$ & 0,129 \\
\hline \multicolumn{3}{|c|}{ B. Patents from Non scientific firms } & \multicolumn{4}{|c|}{ C. Patents from Scientific firms } \\
\hline Forward Citation & 321 & 0,79 & 865 & 1,19 & $-3,94$ & 0,000 \\
\hline Intensity citation & 321 & 0,48 & 865 & 0,66 & $-3,004$ & 0,001 \\
\hline generality & 86 & 0,09 & 301 & 0,10 & $-0,066$ & 0,473 \\
\hline No. IPC clases & 321 & 0,88 & 865 & 1,36 & $-5,37$ & 0,000 \\
\hline Geographic scope & 114 & 0,15 & 379 & 0,19 & $-1,657$ & 0,049 \\
\hline \multicolumn{3}{|c|}{ D. No NPR patents from Scientific firms } & \multicolumn{4}{|c|}{ E. NPR-Patents from Scientific firms } \\
\hline Forward Citation & 762 & 1,20 & 103 & 1,18 & 0,04 & 0,516 \\
\hline Intensity citation & 762 & 0,67 & 103 & 0,61 & 0,379 & 0,647 \\
\hline generality & 275 & 0,09 & 26 & 0,16 & $-1,613$ & 0,059 \\
\hline No. IPC clases & 762 & 1,33 & 103 & 1,56 & $-1,238$ & 0,108 \\
\hline Geographic scope & 340 & 0,19 & 39 & 0,21 & $-0,415$ & 0,339 \\
\hline \multicolumn{3}{|c|}{ F. No NPR patents from Non Scientific firms } & \multicolumn{4}{|c|}{ G. NPR-Patents from Non Scientific firms } \\
\hline Forward Citation & 294 & 0,79 & 27 & 0,78 & 0,039 & 0,518 \\
\hline Intensity citation & 294 & 0,48 & 27 & 0,44 & 0,281 & 0,609 \\
\hline generality & 80 & 0,08 & 6 & 0,24 & $-1,426$ & * \\
\hline No. IPC clases & 294 & 0,86 & 27 & 1,07 & $-0,608$ & 0,276 \\
\hline Geographic scope & 107 & 0,14 & 7 & 0,33 & $-1,531$ & * \\
\hline \multicolumn{3}{|c|}{ G. NPR-Patents from Non Scientific firms } & \multicolumn{4}{|c|}{ E. NPR-Patents from Scientific firms } \\
\hline Forward Citation & 27 & 0,78 & 103 & 1,18 & $-1,066$ & 0,144 \\
\hline Intensity citation & 27 & 0,44 & 103 & 0,61 & $-0,803$ & 0,212 \\
\hline generality & 6 & 0,24 & 26 & 0,16 & 0,696 & $*$ \\
\hline No. IPC clases $(8)$ & 27 & 1,07 & 103 & 1,56 & $-1,253$ & 0,108 \\
\hline Geographic scope & 7 & 0,33 & 39 & 0,21 & 0,899 & $*$ \\
\hline \multicolumn{3}{|c|}{ F. No NPR patents from Non scientific firms } & \multicolumn{4}{|c|}{ D. No NPR patents from Scientific firms } \\
\hline Forward Citation & 294 & 0,79 & 762 & 1,20 & $-3,831$ & 0,001 \\
\hline Intensity citation & 294 & 0,48 & 762 & 0,67 & $-2,95$ & 0,001 \\
\hline generality & 80 & 0,08 & 275 & 0,09 & $-0,274$ & 0,391 \\
\hline No. IPC clases & 294 & 0,86 & 762 & 1,33 & $-5,152$ & 0,001 \\
\hline Geographic scope & 107 & 0,14 & 340 & 0,19 & $-2,008$ & 0,023 \\
\hline
\end{tabular}


Table 5: Correlation Matrix

\begin{tabular}{|c|c|c|c|c|c|c|c|c|c|c|c|c|c|c|c|c|c|}
\hline Forward citation (EP WIPO) & 1 & 1 & 2 & 3 & 4 & 5 & 6 & 7 & 8 & 9 & 10 & 11 & 12 & 13 & 14 & 15 & 16 \\
\hline Generality & 2 & $0.3063^{*}$ & 1 & & & & & & & & & & & & & & \\
\hline Age difference & 3 & $0.4656^{*}$ & 0.0238 & 1 & & & & & & & & & & & & & \\
\hline Family size (no. of states) & 4 & 0.0994* & 0.0729 & 0.0024 & 1 & & & & & & & & & & & & \\
\hline No. Sub fields (4 digit IPC) & 5 & $0.1263^{*}$ & 0.0267 & $0.0730^{*}$ & $-0.1433^{*}$ & 1 & & & & & & & & & & & \\
\hline Unique sub class IPC ( 4 digit) & 6 & $-0.1028^{*}$ & $-0.1089 *$ & $-0.0620^{*}$ & $-0.0690^{*}$ & $-0.0592^{*}$ & 1 & & & & & & & & & & \\
\hline Patent citations made & 7 & -0.0345 & 0.0128 & -0.0255 & $-0.0516^{*}$ & $-0.0618^{*}$ & $-0.1105^{*}$ & 1 & & & & & & & & & \\
\hline Past patenting inventors & 8 & $0.1485^{*}$ & 0.0335 & $0.1200^{*}$ & $-0.0821^{*}$ & $0.3591^{*}$ & $-0.0691^{*}$ & -0.0319 & & & & & & & & & \\
\hline Scientific Non patent reference & 9 & 0.0312 & 0.0626 & $-0.0534^{*}$ & $0.0746^{*}$ & -0.0245 & $-0.0638^{*}$ & $-0.0750^{*}$ & 0.0183 & 1 & & & & & & & \\
\hline Firm size (employees) & 10 & 0.0393 & 0.0518 & -0.0317 & -0.0296 & $0.1721^{*}$ & -0.0182 & $-0.0952^{*}$ & 0.0039 & $0.1054 *$ & 1 & & & & & & \\
\hline Count of publications & 11 & $0.2851^{*}$ & 0.0625 & 0.0248 & $0.3210^{*}$ & $0.1727^{*}$ & $-0.1923^{*}$ & $-0.1283^{*}$ & 0.0431 & $0.1735^{*}$ & $0.1204 *$ & 1 & & & & & \\
\hline Count of co-publications & 12 & $0.2859^{*}$ & 0.0656 & 0.0223 & $0.3023^{*}$ & $0.2110^{*}$ & $-0.1963^{*}$ & $-0.1384^{*}$ & 0.0400 & $0.1716^{*}$ & $0.1411^{*}$ & $0.9959^{*}$ & 1 & & & & \\
\hline Scientific firm dummy & 13 & $0.0727^{*}$ & $0.0889^{*}$ & -0.0281 & $0.0983^{*}$ & $0.0762^{*}$ & $-0.0989^{*}$ & -0.0271 & -0.0113 & $0.0926^{*}$ & $0.3563^{*}$ & $0.1523 *$ & $0.1744^{*}$ & 1 & & & \\
\hline Co-publication intensity & 14 & $-0.1364 *$ & -0.0110 & $-0.1588^{*}$ & $-0.1310^{*}$ & $0.0608^{*}$ & -0.0154 & -0.0169 & -0.0028 & $0.0762^{*}$ & $0.4481^{*}$ & -0.0288 & -0.0065 & $0.5865^{*}$ & & & \\
\hline Cooperating firms (with universities/PRO) dummy & 15 & $0.0992^{*}$ & 0.0517 & 0.0340 & $-0.1065^{*}$ & $0.4231^{*}$ & -0.0055 & $-0.1708^{*}$ & 0.0395 & 0.0377 & $0.3089 *$ & $0.2288^{*}$ & $0.2727^{*}$ & 0.0449 & 1 & & \\
\hline Use of public information sources (dummy) & 16 & $0.1018^{*}$ & $0.0831^{*}$ & $-0.0505^{*}$ & $0.0498^{*}$ & $0.3838^{*}$ & $-0.1217^{*}$ & $-0.1139^{*}$ & 0.0105 & 0.0379 & $0.2433^{*}$ & $0.3592 *$ & $0.4265^{*}$ & $0.2868^{*}$ & $0.4913^{*}$ & 1 & \\
\hline Cooperation and Use of public sources & 17 & $0.1232 *$ & $0.0909^{*}$ & -0.0224 & $0.0510^{*}$ & $0.4211^{*}$ & $-0.1340^{*}$ & $-0.1365^{*}$ & 0.0093 & 0.0288 & $0.2346^{*}$ & $0.3813^{*}$ & $0.4529 *$ & $0.2855^{*}$ & $0.5995^{*}$ & $0.9439^{*}$ & 1 \\
\hline
\end{tabular}

Note: * Significance of correlation at $5 \%$ and better 
Table 5

Explained Variable: Forward patent citation counts (EPO and EPO-WIPO patents)

\begin{tabular}{|c|c|c|c|c|c|c|c|c|}
\hline & \multicolumn{2}{|c|}{ Negative Binomial } & \multicolumn{6}{|c|}{ Zero Inflated Negative Binomial } \\
\hline & 1 & 2 & 3 & 4 & 5 & 6 & 7 & 8 \\
\hline & Count & Count & Count & Logit & Count & Logit & Count & Logit \\
\hline \multicolumn{9}{|l|}{ Patent Characteristics } \\
\hline Backward citation lag & $\begin{array}{c}0.359 \\
(0.038)^{* *}\end{array}$ & $\begin{array}{c}0.106 \\
(0.014)^{* *}\end{array}$ & $\begin{array}{c}0.106 \\
(0.014)^{* *}\end{array}$ & $\begin{array}{c}-1.859 \\
(0.217)^{* *}\end{array}$ & $\begin{array}{c}0.106 \\
(0.014)^{* *}\end{array}$ & $\begin{array}{c}-1.891 \\
(0.220)^{* *}\end{array}$ & $\begin{array}{c}0.109 \\
(0.013)^{* *}\end{array}$ & $\begin{array}{c}-1.885 \\
(0.220)^{* *}\end{array}$ \\
\hline No. of Sub-subclasses & $\begin{array}{c}0.074 \\
(0.039)\end{array}$ & $\begin{array}{c}0.082 \\
(0.027)^{* *}\end{array}$ & $\begin{array}{c}0.082 \\
(0.027)^{* *}\end{array}$ & $\begin{array}{c}0.022 \\
(0.071)\end{array}$ & $\begin{array}{c}0.083 \\
(0.028)^{* *}\end{array}$ & $\begin{array}{c}0.031 \\
(0.071)\end{array}$ & $\begin{array}{c}0.065 \\
(0.017)^{* *}\end{array}$ & $\begin{array}{c}0.032 \\
(0.078)\end{array}$ \\
\hline Single IPC (4 digit) & $\begin{array}{l}-0.073 \\
(0.147)\end{array}$ & $\begin{array}{c}-0.129 \\
(0.079)\end{array}$ & $\begin{array}{l}-0.129 \\
(0.079)\end{array}$ & $\begin{array}{c}-0.314 \\
(0.277)\end{array}$ & $\begin{array}{l}-0.127 \\
(0.079)\end{array}$ & $\begin{array}{c}-0.316 \\
(0.289)\end{array}$ & $\begin{array}{l}-0.141 \\
(0.079)\end{array}$ & $\begin{array}{c}-0.350 \\
(0.285)\end{array}$ \\
\hline Family size (EP) & $\begin{array}{c}0.112 \\
(0.168)\end{array}$ & $\begin{array}{c}0.270 \\
(0.067)^{* *}\end{array}$ & $\begin{array}{c}0.270 \\
(0.067)^{* *}\end{array}$ & $\begin{array}{c}0.267 \\
(0.289)\end{array}$ & $\begin{array}{c}0.272 \\
(0.067)^{* *}\end{array}$ & $\begin{array}{c}0.282 \\
(0.281)\end{array}$ & $\begin{array}{c}0.269 \\
(0.069)^{* *}\end{array}$ & $\begin{array}{c}0.299 \\
(0.281)\end{array}$ \\
\hline No. of inventors & $\begin{array}{c}0.042 \\
(0.200)\end{array}$ & $\begin{array}{c}0.202 \\
(0.091)^{*}\end{array}$ & $\begin{array}{c}0.202 \\
(0.091)^{*}\end{array}$ & $\begin{array}{c}0.227 \\
(0.275)\end{array}$ & $\begin{array}{c}0.198 \\
(0.091)^{*}\end{array}$ & $\begin{array}{c}0.198 \\
(0.277)\end{array}$ & $\begin{array}{c}0.185 \\
(0.098)\end{array}$ & $\begin{array}{c}0.205 \\
(0.262)\end{array}$ \\
\hline Past patenting (inventors) & $\begin{array}{c}0.116 \\
(0.033)^{* *}\end{array}$ & $\begin{array}{c}0.074 \\
(0.027)^{* *}\end{array}$ & $\begin{array}{c}0.074 \\
(0.027)^{* *}\end{array}$ & $\begin{array}{c}-0.072 \\
(0.083)\end{array}$ & $\begin{array}{c}0.075 \\
(0.028)^{* *}\end{array}$ & $\begin{array}{c}-0.064 \\
(0.084)\end{array}$ & $\begin{array}{c}0.058 \\
(0.029)^{*}\end{array}$ & $\begin{array}{c}-0.058 \\
(0.071)\end{array}$ \\
\hline Patent citations made & $\begin{array}{l}-0.120 \\
(0.160)\end{array}$ & $\begin{array}{c}0.099 \\
(0.069)\end{array}$ & $\begin{array}{c}0.099 \\
(0.069)\end{array}$ & $\begin{array}{c}0.366 \\
(0.203)\end{array}$ & $\begin{array}{c}0.100 \\
(0.071)\end{array}$ & $\begin{array}{c}0.358 \\
(0.214)\end{array}$ & $\begin{array}{c}0.129 \\
(0.063)^{*}\end{array}$ & $\begin{array}{c}0.347 \\
(0.230)\end{array}$ \\
\hline Scientific NPR & & $\begin{array}{r}0.258 \\
(0.181) \\
\end{array}$ & $\begin{array}{c}0.258 \\
(0.181) \\
\end{array}$ & $\begin{array}{c}0.172 \\
(0.203) \\
\end{array}$ & $\begin{array}{r}0.262 \\
(0.182) \\
\end{array}$ & $\begin{array}{c}0.254 \\
(0.191) \\
\end{array}$ & $\begin{array}{c}0.251 \\
(0.177) \\
\end{array}$ & $\begin{array}{c}0.250 \\
(0.187) \\
\end{array}$ \\
\hline \multicolumn{9}{|l|}{ Firm Characteristics } \\
\hline $\begin{array}{l}\text { Firm size } \\
\text { Scientific firm }\end{array}$ & & & & & $\begin{array}{c}-0.002 \\
(0.023)\end{array}$ & $\begin{array}{c}-0.163 \\
(0.065)^{*}\end{array}$ & $\begin{array}{c}-0.007 \\
(0.021) \\
0.247 \\
(0.123)^{*}\end{array}$ & $\begin{array}{c}-0.167 \\
(0.066)^{*} \\
-0.060 \\
(0.436)\end{array}$ \\
\hline $\begin{array}{l}\text { Electrical } \\
\text { Engineering }\end{array}$ & 0.478 & 0.300 & 0.300 & -0.304 & 0.303 & -0.346 & 0.270 & -0.354 \\
\hline & $(0.311)^{* *}$ & $(0.154)$ & $(0.154)^{* *}$ & $(0.614)$ & $(0.152)^{* *}$ & $(0.624)$ & $(0.111)^{* *}$ & $(0.619)$ \\
\hline Instruments & $\begin{array}{c}0.286 \\
(0.227)\end{array}$ & $\begin{array}{c}0.077 \\
(0.189)\end{array}$ & $\begin{array}{c}0.077 \\
(0.189)\end{array}$ & $\begin{array}{l}-0.112 \\
(0.354)\end{array}$ & $\begin{array}{c}0.079 \\
(0.188)\end{array}$ & $\begin{array}{c}-0.108 \\
(0.360)\end{array}$ & $\begin{array}{c}0.022 \\
(0.144)\end{array}$ & $\begin{array}{l}-0.114 \\
(0.367)\end{array}$ \\
\hline $\begin{array}{l}\text { Chemistry \& } \\
\text { pharmaceuticals }\end{array}$ & $\begin{array}{c}0.447 \\
(0.331)\end{array}$ & $\begin{array}{c}0.503 \\
(0.372)\end{array}$ & $\begin{array}{c}0.503 \\
(0.372)\end{array}$ & $\begin{array}{c}0.402 \\
(0.428)\end{array}$ & $\begin{array}{c}0.505 \\
(0.376)\end{array}$ & $\begin{array}{c}0.379 \\
(0.443)\end{array}$ & $\begin{array}{c}0.438 \\
(0.367)\end{array}$ & $\begin{array}{c}0.362 \\
(0.469)\end{array}$ \\
\hline Process engineering & $\begin{array}{c}0.308 \\
(0.218)\end{array}$ & $\begin{array}{c}0.085 \\
(0.148)\end{array}$ & $\begin{array}{c}0.085 \\
(0.148)\end{array}$ & $\begin{array}{l}-0.206 \\
(0.489)\end{array}$ & $\begin{array}{c}0.085 \\
(0.150)\end{array}$ & $\begin{array}{l}-0.231 \\
(0.503)\end{array}$ & $\begin{array}{c}0.071 \\
(0.114)\end{array}$ & $\begin{array}{l}-0.262 \\
(0.509)\end{array}$ \\
\hline y1998_y2001 & $\begin{array}{l}-0.126 \\
(0.162)\end{array}$ & $\begin{array}{c}-0.195 \\
(0.072)^{* *}\end{array}$ & $\begin{array}{c}-0.195 \\
(0.072)^{* *}\end{array}$ & $\begin{array}{l}-0.181 \\
(0.379)\end{array}$ & $\begin{array}{c}-0.197 \\
(0.074)^{* *}\end{array}$ & $\begin{array}{l}-0.198 \\
(0.393)\end{array}$ & $\begin{array}{c}-0.202 \\
(0.077)^{* *}\end{array}$ & $\begin{array}{l}-0.193 \\
(0.391)\end{array}$ \\
\hline y1994_y1997 & $\begin{array}{l}-0.179 \\
(0.442)\end{array}$ & $\begin{array}{l}-0.034 \\
(0.158)\end{array}$ & $\begin{array}{l}-0.034 \\
(0.158)\end{array}$ & $\begin{array}{c}0.064 \\
(0.361)\end{array}$ & $\begin{array}{l}-0.028 \\
(0.155)\end{array}$ & $\begin{array}{c}0.034 \\
(0.378)\end{array}$ & $\begin{array}{l}-0.057 \\
(0.156)\end{array}$ & $\begin{array}{c}0.025 \\
(0.373)\end{array}$ \\
\hline Constant & $\begin{array}{l}-1.294 \\
(0.868)\end{array}$ & $\begin{array}{c}-0.864 \\
(0.245)^{* *}\end{array}$ & $\begin{array}{c}-0.864 \\
(0.245)^{* *}\end{array}$ & $\begin{array}{l}-0.314 \\
(1.395)\end{array}$ & $\begin{array}{c}-0.859 \\
(0.321)^{* *}\end{array}$ & $\begin{array}{c}0.950 \\
(1.789)\end{array}$ & $\begin{array}{c}-0.898 \\
(0.331)^{* *}\end{array}$ & $\begin{array}{c}1.002 \\
(1.888)\end{array}$ \\
\hline Observations & 1185 & 1185 & 1185 & 1185 & 1185 & 1185 & 1185 & 1185 \\
\hline $\begin{array}{l}\text { Dispersion Parameter } \\
\text { (ln alpha) }\end{array}$ & 1.05 & 1.05 & $-1.28 * *$ & & $-1.28 * *$ & & $-1.29 * *$ & \\
\hline Overdispersion Test $(\mathrm{alpha}=0)$ & $451.48 * * *$ & $451.52 * * *$ & $99.72 * * *$ & & & & & \\
\hline Wald Test (Joint Sig.) & 5829.50 & 5480.36 & $1278.81 * * *$ & & $1340.26 * * *$ & & $1431.88 * * *$ & \\
\hline $\begin{array}{l}\text { Log Pseudo Likelihood } \\
\text { Vuong Test (zinb vs negative } \\
\text { binomial) }\end{array}$ & -1529.13 & -1527.35 & $\begin{array}{l}-1412.3 \\
5.99 * * *\end{array}$ & & -1409.686 & & -1406.872 & \\
\hline
\end{tabular}

Note: Robust standard errors in parentheses. Standard errors clustered by firm. The log-likelihood ratio test discriminating betzeen zero inflated poisson and zero inflated negative binomial : 99.75 (significance $<1 \%$ ). Assumption in the LHR Test zip versus zinb: zip nested in zinb.

$* * * \mathrm{p}<0.01, * * \mathrm{p}<0.05, * \mathrm{p}<0.1$ 
Table 6

Explained Variable: Forward patent citation counts (EPO and EPO-WIPO patents)

\begin{tabular}{|c|c|c|c|c|c|c|}
\hline \multirow[t]{2}{*}{ (2) } & \multicolumn{2}{|c|}{$\begin{array}{c}\text { Non NPR Patent } \\
\text { Whole Sample } \\
\end{array}$} & \multicolumn{2}{|c|}{$\begin{array}{c}\text { Science Intensive } \\
\text { Technologies } \\
\end{array}$} & \multicolumn{2}{|c|}{$\begin{array}{c}\text { Non NPR Patents } \\
\text { Science Intensive } \\
\text { Tech. } \\
\end{array}$} \\
\hline & $\begin{array}{c}1 \\
\text { count } \\
\end{array}$ & $\begin{array}{c}2 \\
\text { logit } \\
\end{array}$ & $\begin{array}{c}3 \\
\text { count } \\
\end{array}$ & $\begin{array}{c}4 \\
\text { logit } \\
\end{array}$ & $\begin{array}{c}5 \\
\text { count } \\
\end{array}$ & $\begin{array}{c}6 \\
\text { logit } \\
\end{array}$ \\
\hline \multicolumn{7}{|l|}{ Patent Characteristics } \\
\hline Backward citation lag & $\begin{array}{c}0.119 \\
(0.017)^{* *}\end{array}$ & $\begin{array}{c}-1.957 \\
(0.250)^{* *}\end{array}$ & $\begin{array}{c}0.109 \\
(0.030)^{* *}\end{array}$ & $\begin{array}{c}-1.741 \\
(0.370)^{* *}\end{array}$ & $\begin{array}{c}0.088 \\
(0.031)^{* *}\end{array}$ & $\begin{array}{c}-1.740 \\
(0.375)^{* *}\end{array}$ \\
\hline No. of Sub-subclasses & $\begin{array}{c}0.083 \\
(0.038)^{*}\end{array}$ & $\begin{array}{c}0.055 \\
(0.080)\end{array}$ & $\begin{array}{c}0.075 \\
(0.063)\end{array}$ & $\begin{array}{c}-0.017 \\
(0.108)\end{array}$ & $\begin{array}{c}0.067 \\
(0.072)\end{array}$ & $\begin{array}{l}-0.038 \\
(0.108)\end{array}$ \\
\hline Single IPC(4) patents & $\begin{array}{c}-0.151 \\
(0.077)^{*}\end{array}$ & $\begin{array}{l}-0.468 \\
(0.345)\end{array}$ & $\begin{array}{l}-0.098 \\
(0.137)\end{array}$ & $\begin{array}{l}-0.300 \\
(0.277)\end{array}$ & $\begin{array}{l}-0.112 \\
(0.147)\end{array}$ & $\begin{array}{l}-0.289 \\
(0.283)\end{array}$ \\
\hline Patent citations made & $\begin{array}{c}0.143 \\
(0.063)^{*}\end{array}$ & $\begin{array}{c}0.414 \\
(0.257)\end{array}$ & $\begin{array}{c}0.146 \\
(0.138)\end{array}$ & $\begin{array}{c}0.007 \\
(0.323)\end{array}$ & $\begin{array}{c}0.110 \\
(0.140)\end{array}$ & $\begin{array}{l}-0.033 \\
(0.320)\end{array}$ \\
\hline Family size (EP) & $\begin{array}{c}0.248 \\
(0.070)^{* *}\end{array}$ & $\begin{array}{c}0.181 \\
(0.279)\end{array}$ & $\begin{array}{c}0.322 \\
(0.134)^{*}\end{array}$ & $\begin{array}{c}0.611 \\
(0.270)^{*}\end{array}$ & $\begin{array}{c}0.328 \\
(0.139)^{*}\end{array}$ & $\begin{array}{c}0.573 \\
(0.268)^{*}\end{array}$ \\
\hline No. of inventors & $\begin{array}{c}0.257 \\
(0.067)^{* *}\end{array}$ & $\begin{array}{c}0.180 \\
(0.292)\end{array}$ & $\begin{array}{c}0.163 \\
(0.165)\end{array}$ & $\begin{array}{l}-0.039 \\
(0.396)\end{array}$ & $\begin{array}{c}0.162 \\
(0.171)\end{array}$ & $\begin{array}{l}-0.095 \\
(0.396)\end{array}$ \\
\hline Past patents (inventors) & $\begin{array}{c}0.064 \\
(0.035)\end{array}$ & $\begin{array}{l}-0.076 \\
(0.076)\end{array}$ & $\begin{array}{c}0.046 \\
(0.070)\end{array}$ & $\begin{array}{c}0.099 \\
(0.142)\end{array}$ & $\begin{array}{c}0.045 \\
(0.072)\end{array}$ & $\begin{array}{c}0.071 \\
(0.143)\end{array}$ \\
\hline Scientific NPR & & & $\begin{array}{c}0.391 \\
(0.195)^{*} \\
\end{array}$ & $\begin{array}{c}0.099 \\
(0.351) \\
\end{array}$ & & \\
\hline \multicolumn{7}{|l|}{ Firm Characteristics } \\
\hline Firm size & $\begin{array}{l}-0.011 \\
(0.019)\end{array}$ & $\begin{array}{c}-0.169 \\
(0.061)^{* *}\end{array}$ & $\begin{array}{c}-0.004 \\
(0.061)\end{array}$ & $\begin{array}{c}-0.279 \\
(0.097)^{* *}\end{array}$ & $\begin{array}{c}0.005 \\
(0.062)\end{array}$ & $\begin{array}{c}-0.267 \\
(0.097)^{* *}\end{array}$ \\
\hline Scientific firm & $\begin{array}{c}0.245 \\
(0.122)^{*}\end{array}$ & $\begin{array}{c}0.077 \\
(0.435)\end{array}$ & $\begin{array}{c}0.519 \\
(0.272)\end{array}$ & $\begin{array}{c}0.385 \\
(0.512)\end{array}$ & $\begin{array}{c}0.550 \\
(0.319)\end{array}$ & $\begin{array}{c}0.563 \\
(0.559)\end{array}$ \\
\hline Electrical Engineering & $\begin{array}{c}0.225 \\
(0.111)^{*}\end{array}$ & $\begin{array}{l}-0.319 \\
(0.595)\end{array}$ & & & & \\
\hline Instruments & $\begin{array}{l}-0.032 \\
(0.195)\end{array}$ & $\begin{array}{l}-0.136 \\
(0.403)\end{array}$ & $\begin{array}{l}-0.284 \\
(0.167)\end{array}$ & $\begin{array}{c}0.242 \\
(0.381)\end{array}$ & $\begin{array}{l}-0.237 \\
(0.176)\end{array}$ & $\begin{array}{c}0.269 \\
(0.401)\end{array}$ \\
\hline Chemistry/pharmaceuticals & $\begin{array}{c}0.106 \\
(0.324)\end{array}$ & $\begin{array}{c}0.476 \\
(0.575)\end{array}$ & $\begin{array}{c}0.092 \\
(0.228)\end{array}$ & $\begin{array}{c}0.570 \\
(0.416)\end{array}$ & $\begin{array}{c}0.191 \\
(0.256)\end{array}$ & $\begin{array}{c}0.616 \\
(0.429)\end{array}$ \\
\hline Process engineering/equipment & $\begin{array}{c}0.041 \\
(0.117)\end{array}$ & $\begin{array}{l}-0.282 \\
(0.523)\end{array}$ & & & & \\
\hline y1998_y2001 & $\begin{array}{c}-0.238 \\
(0.071)^{* *}\end{array}$ & $\begin{array}{l}-0.469 \\
(0.375)\end{array}$ & $\begin{array}{l}-0.246 \\
(0.128)\end{array}$ & $\begin{array}{c}0.078 \\
(0.283)\end{array}$ & $\begin{array}{l}-0.238 \\
(0.133)\end{array}$ & $\begin{array}{c}0.017 \\
(0.287)\end{array}$ \\
\hline y1994_y1997 & $\begin{array}{l}-0.052 \\
(0.176)\end{array}$ & $\begin{array}{l}-0.242 \\
(0.269)\end{array}$ & $\begin{array}{l}-0.181 \\
(0.201)\end{array}$ & $\begin{array}{c}0.435 \\
(0.385)\end{array}$ & $\begin{array}{l}-0.244 \\
(0.213)\end{array}$ & $\begin{array}{c}0.379 \\
(0.385)\end{array}$ \\
\hline Constant & $\begin{array}{c}-0.963 \\
(0.312)^{* *}\end{array}$ & $\begin{array}{c}1.241 \\
(1.865)\end{array}$ & $\begin{array}{l}-0.992 \\
(0.578)\end{array}$ & $\begin{array}{c}0.959 \\
(1.339)\end{array}$ & $\begin{array}{l}-0.967 \\
(0.604)\end{array}$ & $\begin{array}{c}1.089 \\
(1.325)\end{array}$ \\
\hline Observations & 1055 & 1055 & 719 & 719 & 703 & 703 \\
\hline Dispersion Parameter (ln alpha) & -1.28 & & -1.16 & & -1.12 & \\
\hline Overdispersion Test & $69.51 * * *$ & & $77.60 * * *$ & & $78.57 * * *$ & \\
\hline Wald Test (Joint Sig.) & $412.28 * * *$ & & $56.86 * * *$ & & $49.40 * * *$ & \\
\hline $\begin{array}{l}\text { Log Pseudo Likelihood } \\
\text { Vuong Test (zinb vs negative } \\
\text { binomial) }\end{array}$ & $\begin{array}{l}-1248.32 \\
5.12 * * * \\
\end{array}$ & & $\begin{array}{l}-856.05 \\
5.90 * * * \\
\end{array}$ & & $\begin{array}{r}-832.5921 \\
5.64 * * * \\
\end{array}$ & \\
\hline
\end{tabular}

Note: Robust standard errors clustered by firm in model displayed in columns 1 and 2. The goodness' of the fit is reporting in the LHR ratio test instead of the Wald test for the rest of the models (science intensive technologies) since they are not robust to clustering by firms (26 firms only). For the sub-sample of science intensive technologies, the Vuong Test discriminating between zinb versus negative binomial $=5,67$ with $\mathrm{Pr}>\mathrm{z}=0,0000$. The Science intensive technologies are: electrical engineering, instruments and chemical and pharmaceuticals (Franhuffer' technology classes).

$* * * \mathrm{p}<0.01, * * \mathrm{p}<0.05, * \mathrm{p}<0.1$ 
Table 7

Explained Variable: Forward patent citation counts (EPO and EPO-WIPO patents)

Firm Level Science Linkages and Interactions (count regressions of the Zero Inflated Negative Binomial)

\begin{tabular}{|c|c|c|c|c|c|c|c|c|c|}
\hline \multirow[b]{2}{*}{ Patent Characteristics } & \multicolumn{5}{|c|}{ Other ISL at the firm level } & \multicolumn{4}{|c|}{ Interactions } \\
\hline & 1 & 2 & 3 & 4 & 5 & 6 & 7 & 8 & 9 \\
\hline Backward citation lag & $\begin{array}{c}0.110 \\
\left(0.0111^{* *}\right.\end{array}$ & $\begin{array}{c}0.110 \\
\left(0.0111^{* * *}\right.\end{array}$ & $\begin{array}{c}0.108 \\
(0.011)^{* *}\end{array}$ & $\begin{array}{c}0.110 \\
\left(0.0111^{* * *}\right.\end{array}$ & $\begin{array}{c}0.110 \\
\left(0.0111^{* * *}\right.\end{array}$ & $\begin{array}{c}0.110 \\
(0.011)^{* *}\end{array}$ & $\begin{array}{c}0.110 \\
0.0111^{* * *}\end{array}$ & $\begin{array}{c}0.110 \\
\left(0.0111^{* *}\right.\end{array}$ & $\begin{array}{c}0.111 \\
(0.012)^{* *}\end{array}$ \\
\hline No. of Sub-subclasses & $\begin{array}{c}0.057 \\
(0.019 * * *\end{array}$ & $\begin{array}{c}0.063 \\
(0.022)^{* *}\end{array}$ & $\begin{array}{c}0.066 \\
(0.022)^{* *}\end{array}$ & $\begin{array}{c}0.057 \\
\left(0.0199^{* *}\right.\end{array}$ & $\begin{array}{c}0.055 \\
(0.018)^{* *}\end{array}$ & $\begin{array}{c}0.057 \\
(0.018)^{* *}\end{array}$ & $\begin{array}{c}0.055 \\
(0.018)^{* *}\end{array}$ & $\begin{array}{c}0.057 \\
(0.019 * * *\end{array}$ & $\begin{array}{c}0.053 \\
(0.018)^{* *}\end{array}$ \\
\hline Single IPC(4) patents & $\begin{array}{c}-0.148 \\
(0.073)^{*}\end{array}$ & $\begin{array}{c}-0.147 \\
(0.071)^{*}\end{array}$ & $\begin{array}{l}-0.143 \\
(0.073)\end{array}$ & $\begin{array}{c}-0.149 \\
(0.072)^{*}\end{array}$ & $\begin{array}{c}-0.151 \\
(0.072)^{*}\end{array}$ & $\begin{array}{c}-0.148 \\
(0.073)^{*}\end{array}$ & $\begin{array}{c}-0.150 \\
(0.073)^{*}\end{array}$ & $\begin{array}{c}-0.146 \\
(0.073)^{*}\end{array}$ & $\begin{array}{c}-0.151 \\
(0.075)^{*}\end{array}$ \\
\hline Patent citations made & $\begin{array}{c}0.115 \\
(0.056)^{*}\end{array}$ & $\begin{array}{c}0.111 \\
(0.057)\end{array}$ & $\begin{array}{c}0.100 \\
(0.060)\end{array}$ & $\begin{array}{c}0.116 \\
(0.055)^{*}\end{array}$ & $\begin{array}{c}0.118 \\
(0.056)^{*}\end{array}$ & $\begin{array}{c}0.115 \\
(0.056)^{*}\end{array}$ & $\begin{array}{c}0.119 \\
(0.054)^{*}\end{array}$ & $\begin{array}{c}0.113 \\
(0.056) *\end{array}$ & $\begin{array}{c}0.119 \\
(0.054)^{*}\end{array}$ \\
\hline Family size (EP) & $\begin{array}{c}0.289 \\
(0.075)^{* *}\end{array}$ & $\begin{array}{c}0.297 \\
(0.072)^{* *}\end{array}$ & $\begin{array}{c}0.298 \\
(0.071)^{* *}\end{array}$ & $\begin{array}{c}0.290 \\
(0.076)^{* *}\end{array}$ & $\begin{array}{c}0.291 \\
(0.077)^{* *}\end{array}$ & $\begin{array}{c}0.289 \\
(0.076)^{* *}\end{array}$ & $\begin{array}{c}0.290 \\
(0.075)^{* *}\end{array}$ & $\begin{array}{c}0.285 \\
(0.077)^{* *}\end{array}$ & $\begin{array}{c}0.286 \\
(0.077)^{* *}\end{array}$ \\
\hline Past patents (inventors) & $\begin{array}{c}0.085 \\
(0.029)^{* *}\end{array}$ & $\begin{array}{c}0.086 \\
(0.031)^{* *}\end{array}$ & $\begin{array}{c}0.098 \\
(0.031)^{* *}\end{array}$ & $\begin{array}{c}0.084 \\
(0.030)^{* *}\end{array}$ & $\begin{array}{c}0.084 \\
(0.030)^{* *}\end{array}$ & $\begin{array}{c}0.085 \\
(0.029)^{* *}\end{array}$ & $\begin{array}{c}0.085 \\
(0.032)^{* *}\end{array}$ & $\begin{array}{c}0.086 \\
(0.031)^{* *}\end{array}$ & $\begin{array}{c}0.087 \\
(0.031)^{* *}\end{array}$ \\
\hline Scientific NPR & $\begin{array}{c}0.244 \\
(0.190) \\
\end{array}$ & $\begin{array}{c}0.251 \\
(0.194) \\
\end{array}$ & $\begin{array}{r}0.240 \\
(0.187) \\
\end{array}$ & $\begin{array}{c}0.245 \\
(0.191) \\
\end{array}$ & $\begin{array}{c}0.242 \\
(0.189) \\
\end{array}$ & $\begin{array}{r}0.223 \\
(0.229) \\
\end{array}$ & $\begin{array}{c}0.065 \\
(0.332) \\
\end{array}$ & $\begin{array}{c}0.214 \\
(0.227) \\
\end{array}$ & $\begin{array}{c}0.027 \\
(0.343)\end{array}$ \\
\hline Firm Characteristics & & & & & & & & & \\
\hline Firm size & $\begin{array}{l}-0.009 \\
(0.022)\end{array}$ & $\begin{array}{l}-0.015 \\
(0.024)\end{array}$ & $\begin{array}{c}-0.013 \\
(0.024)\end{array}$ & $\begin{array}{l}-0.010 \\
(0.023)\end{array}$ & $\begin{array}{c}-0.012 \\
(0.021)\end{array}$ & $\begin{array}{l}-0.009 \\
(0.022)\end{array}$ & $\begin{array}{c}-0.012 \\
(0.020)\end{array}$ & $\begin{array}{c}-0.006 \\
(0.021)\end{array}$ & $\begin{array}{c}-0.009 \\
(0.020)\end{array}$ \\
\hline Scientific firm & $\begin{array}{c}0.271 \\
(0.117)^{*}\end{array}$ & & & $\begin{array}{c}0.251 \\
(0.222)\end{array}$ & $\begin{array}{c}0.250 \\
(0.216)\end{array}$ & $\begin{array}{c}0.269 \\
(0.117)^{*}\end{array}$ & $\begin{array}{c}0.247 \\
(0.087)^{* *}\end{array}$ & $\begin{array}{c}0.351 \\
(0.208)\end{array}$ & $\begin{array}{c}0.388 \\
(0.235)\end{array}$ \\
\hline Use of Public sources (CIS) & & $\begin{array}{c}0.239 \\
(0.111)^{*}\end{array}$ & & $\begin{array}{c}0.025 \\
(0.217)\end{array}$ & $\begin{array}{c}0.006 \\
(0.226)\end{array}$ & & & $\begin{array}{l}-0.100 \\
(0.205)\end{array}$ & $\begin{array}{c}-0.201 \\
(0.249)\end{array}$ \\
\hline Cooperating firms (CIS) & & & $\begin{array}{c}0.170 \\
(0.170)\end{array}$ & & $\begin{array}{c}0.049 \\
(0.167)\end{array}$ & & $\begin{array}{c}0.056 \\
(0.175)\end{array}$ & & $\begin{array}{c}0.125 \\
(0.221)\end{array}$ \\
\hline Scientific NPR*scientific firm & & & & & & $\begin{array}{c}0.025 \\
(0.342)\end{array}$ & & & $\begin{array}{c}0.106 \\
(0.323)\end{array}$ \\
\hline Scientific NPR*Cooperating firm & & & & & & & $\begin{array}{c}0.179 \\
(0.477)\end{array}$ & & $\begin{array}{c}0.121 \\
(0.431)\end{array}$ \\
\hline Scientific NPR*Public Sources & & & & & & & & $\begin{array}{c}0.027 \\
(0.338)\end{array}$ & \\
\hline Electrical Engineering & $\begin{array}{c}0.295 \\
(0.117)^{*}\end{array}$ & $\begin{array}{c}0.216 \\
(0.171)^{*}\end{array}$ & $\begin{array}{c}0.250 \\
(0.213)^{*}\end{array}$ & $\begin{array}{c}0.285 \\
(0.164)^{*}\end{array}$ & $\begin{array}{c}0.270 \\
(0.176)^{*}\end{array}$ & $\begin{array}{c}0.297 \\
(0.116)^{*}\end{array}$ & $\begin{array}{c}0.268 \\
(0.160)\end{array}$ & $\begin{array}{c}0.340 \\
(0.160)^{*}\end{array}$ & $\begin{array}{c}0.321 \\
(0.169)\end{array}$ \\
\hline Instruments & $\begin{array}{c}0.060 \\
(0.162)\end{array}$ & $\begin{array}{c}-0.016 \\
(0.214)\end{array}$ & $\begin{array}{c}0.056 \\
(0.234)\end{array}$ & $\begin{array}{c}0.049 \\
(0.192)\end{array}$ & $\begin{array}{c}0.038 \\
(0.197)\end{array}$ & $\begin{array}{c}0.062 \\
(0.156)\end{array}$ & $\begin{array}{c}0.041 \\
(0.190)\end{array}$ & $\begin{array}{c}0.104 \\
(0.199)\end{array}$ & $\begin{array}{c}0.095 \\
(0.196)\end{array}$ \\
\hline Chemistry/pharmaceuticals & $\begin{array}{c}0.470 \\
(0.340)\end{array}$ & $\begin{array}{c}0.390 \\
(0.359)\end{array}$ & $\begin{array}{c}0.472 \\
(0.382)\end{array}$ & $\begin{array}{c}0.458 \\
(0.365)\end{array}$ & $\begin{array}{c}0.447 \\
(0.370)\end{array}$ & $\begin{array}{c}0.471 \\
(0.349)\end{array}$ & $\begin{array}{c}0.452 \\
(0.371)\end{array}$ & $\begin{array}{c}0.519 \\
(0.373)\end{array}$ & $\begin{array}{c}0.511 \\
(0.385)\end{array}$ \\
\hline Process engineering/equipment & $\begin{array}{c}0.102 \\
(0.115)\end{array}$ & $\begin{array}{c}0.030 \\
(0.171)\end{array}$ & $\begin{array}{c}0.057 \\
(0.204)\end{array}$ & $\begin{array}{c}0.093 \\
(0.155)\end{array}$ & $\begin{array}{c}0.079 \\
(0.169)\end{array}$ & $\begin{array}{c}0.103 \\
(0.114)\end{array}$ & $\begin{array}{c}0.078 \\
(0.159)\end{array}$ & $\begin{array}{c}0.140 \\
(0.155)\end{array}$ & $\begin{array}{c}0.118 \\
(0.165)\end{array}$ \\
\hline |y1998_y2001 & $\begin{array}{c}-0.249 \\
(0.041)^{* *}\end{array}$ & $\begin{array}{c}0.250 \\
(0.042)^{* *}\end{array}$ & $\begin{array}{c}-0.187 \\
(0.046)^{* *}\end{array}$ & $\begin{array}{c}0.149 \\
(0.041)^{* *}\end{array}$ & $\begin{array}{c}-0.188 \\
(0.042)^{* *}\end{array}$ & $\begin{array}{c}0.149 \\
(0.043)^{* *}\end{array}$ & $\begin{array}{c}-0.166 \\
(0.045)^{* *}\end{array}$ & $\begin{array}{c}0.146 \\
(0.043)^{* *}\end{array}$ & $\begin{array}{c}-0.151 \\
(0.047)^{* *}\end{array}$ \\
\hline Constant & $\begin{array}{c}-0.910 \\
(0.386)^{*}\end{array}$ & $\begin{array}{c}-0.800 \\
(0.386)^{*}\end{array}$ & $\begin{array}{c}-0.840 \\
(0.402)^{*}\end{array}$ & $\begin{array}{c}-0.900 \\
(0.405)^{*}\end{array}$ & $\begin{array}{c}-0.900 \\
(0.413)^{*}\end{array}$ & $\begin{array}{c}-0.911 \\
(0.386)^{*}\end{array}$ & $\begin{array}{c}-0.900 \\
(0.383)^{*}\end{array}$ & $\begin{array}{c}-0.953 \\
(0.406)^{*}\end{array}$ & $\begin{array}{c}-0.973 \\
(0.431)^{*}\end{array}$ \\
\hline Observations & 1186 & 1186 & 1186 & 1186 & 1186 & 1186 & 1186 & 1186 & 1186 \\
\hline Dispersion Parameter (In alpha) & -1.28 & -1.28 & -1.28 & -1.28 & -1.28 & -1.28 & -1.28 & -1.28 & -1.28 \\
\hline Wald Test (Joint Sig.) & 429.28 & 511.54 & 639.12 & 429.28 & 1654.21 & 471.25 & 3602.43 & 1689.25 & 3199.67 \\
\hline Log Pseudo Likelihood & -1409.547 & -1411.272 & -1412.08 & -1409.547 & -1409.489 & -1409.545 & -1409.365 & -1409.149 & -1408.32 \\
\hline
\end{tabular}

Robust standard errors in parentheses clustered by firm.

$*$ significant at $5 \% \cdot * *$ significant at $1 \%$ 
Table 7

Other indicators of patent quality and diffusion

\begin{tabular}{|c|c|c|c|c|c|c|c|c|c|c|c|c|}
\hline & \multicolumn{4}{|c|}{ Generality } & \multicolumn{4}{|c|}{ Geographical Dispersion } & \multicolumn{4}{|c|}{ Forward Citation Lag } \\
\hline & \multicolumn{2}{|c|}{ Generality } & \multicolumn{2}{|c|}{ Different IPC-4 digit } & \multicolumn{2}{|c|}{ Geographical Dispersion } & \multicolumn{2}{|c|}{ Abroad citation } & \multicolumn{2}{|c|}{ Median Time } & \multicolumn{2}{|c|}{ Shortest time } \\
\hline & Tobit & Tobit & probit & probit & Tobit & Tobit & probit & probit & ols & ols & ols & ols \\
\hline & -1 & -2 & -3 & -4 & -5 & -6 & -7 & -8 & -9 & -10 & -11 & -12 \\
\hline \begin{tabular}{|l|} 
Patent Radicalness \\
\end{tabular} & $\begin{array}{c}0.096^{* * *} \\
(0.017)\end{array}$ & $\begin{array}{c}0.096^{* * *} \\
(0.017\end{array}$ & $0.053^{* * * *}$ & $0.053^{* * *}$ & $0.066^{* * * *}$ & $0.066^{* * *}$ & $0.066^{* * *}$ & $0.066^{* * *}$ & $-0.095^{* * *}$ & $-0.096^{* * * *}$ & 0.007 & 0.007 \\
\hline Backward citation lag & $\begin{array}{c}0.022 \\
(0.025)\end{array}$ & $\begin{array}{c}0.021 \\
(0.025)\end{array}$ & $\begin{array}{c}0.009 \\
(0.009)\end{array}$ & $\begin{array}{c}0.009 \\
(0.009)\end{array}$ & $\begin{array}{l}0.025^{*} \\
(0.015)\end{array}$ & $\begin{array}{l}0.025^{*} \\
(0.015)\end{array}$ & $\begin{array}{l}0.017^{*} \\
(0.009)\end{array}$ & $\begin{array}{l}0.017^{*} \\
(0.009)\end{array}$ & $\begin{array}{c}0.024 \\
(0.051)\end{array}$ & $\begin{array}{c}0.024 \\
(0.051)\end{array}$ & $\begin{array}{c}0.037 \\
(0.055)\end{array}$ & $\begin{array}{c}0.036 \\
(0.056)\end{array}$ \\
\hline No. of Sub-subclasses & $\begin{array}{l}0.011 \\
(0.040)\end{array}$ & $\begin{array}{c}0.009 \\
(0.040)\end{array}$ & $\begin{array}{c}0.004 \\
(0.014)\end{array}$ & $\begin{array}{c}0.003 \\
(0.014)\end{array}$ & $\begin{array}{c}0.028 \\
(0.026)\end{array}$ & $\begin{array}{c}0.028 \\
(0.026)\end{array}$ & $\begin{array}{c}0.024 \\
(0.019)\end{array}$ & $\begin{array}{c}0.025 \\
(0.019)\end{array}$ & $\begin{array}{l}-0.105^{*} \\
(0.056)\end{array}$ & $\begin{array}{l}-0.111^{*} \\
(0.057)\end{array}$ & $\begin{array}{l}-0.085 \\
(0.052)\end{array}$ & $\begin{array}{l}-0.085 \\
(0.052)\end{array}$ \\
\hline Single IPC(4) patents & $\begin{array}{c}-0.208 * * \\
(0.104)\end{array}$ & $\begin{array}{c}-0.214 * * \\
(0.105)\end{array}$ & $\begin{array}{c}-0.090^{* * *} \\
(0.024)\end{array}$ & $\begin{array}{c}-0.092 * * * \\
(0.024)\end{array}$ & $\begin{array}{c}0.043 \\
(0.065)\end{array}$ & $\begin{array}{c}0.045 \\
(0.065)\end{array}$ & $\begin{array}{c}0.035 \\
(0.044)\end{array}$ & $\begin{array}{c}0.035 \\
(0.044)\end{array}$ & $\begin{array}{l}-0.132 \\
(0.229)\end{array}$ & $\begin{array}{l}-0.134 \\
(0.228)\end{array}$ & $\begin{array}{l}-0.165 \\
(0.209)\end{array}$ & $\begin{array}{l}-0.165 \\
(0.208)\end{array}$ \\
\hline Family size (EP) & $\begin{array}{l}-0.071 \\
(0.097)\end{array}$ & $\begin{array}{l}-0.069 \\
(0.097)\end{array}$ & $\begin{array}{l}-0.040 \\
(0.029)\end{array}$ & $\begin{array}{l}-0.039 \\
(0.028)\end{array}$ & $\begin{array}{l}0.024^{*} \\
(0.062)\end{array}$ & $\begin{array}{l}0.024^{*} \\
(0.062)\end{array}$ & $\begin{array}{l}0.020^{*} \\
(0.038)\end{array}$ & $\begin{array}{l}0.020^{*} \\
(0.038)\end{array}$ & $\begin{array}{c}0.154 \\
(0.132)\end{array}$ & $\begin{array}{c}0.158 \\
(0.131)\end{array}$ & $\begin{array}{c}0.203 \\
(0.161)\end{array}$ & $\begin{array}{c}0.203 \\
(0.162)\end{array}$ \\
\hline No. of inventors & $\begin{array}{l}0.262^{*} \\
(0.136)\end{array}$ & $\begin{array}{l}0.265^{*} \\
(0.136)\end{array}$ & $\begin{array}{l}0.115^{* *} \\
(0.055)\end{array}$ & $\begin{array}{l}0.117 * * \\
(0.052)\end{array}$ & $\begin{array}{l}-0.091 \\
(0.090)\end{array}$ & $\begin{array}{l}-0.092 \\
(0.090)\end{array}$ & $\begin{array}{c}-0.091 * * \\
(0.042)\end{array}$ & $\begin{array}{c}-0.092 * * \\
(0.043)\end{array}$ & $\begin{array}{l}0.297^{*} \\
(0.169)\end{array}$ & $\begin{array}{l}0.300^{*} \\
(0.173)\end{array}$ & $\begin{array}{c}0.252 \\
(0.171)\end{array}$ & $\begin{array}{c}0.252 \\
(0.172)\end{array}$ \\
\hline Past patents (inventors) & $\begin{array}{l}-0.019 \\
(0.052)\end{array}$ & $\begin{array}{l}-0.023 \\
(0.052)\end{array}$ & $\begin{array}{l}-0.009 \\
(0.014)\end{array}$ & $\begin{array}{l}-0.011 \\
(0.014)\end{array}$ & $\begin{array}{c}0.052 \\
(0.034)\end{array}$ & $\begin{array}{c}0.053 \\
(0.034)\end{array}$ & $\begin{array}{l}0.046^{* *} \\
(0.021)\end{array}$ & $\begin{array}{c}0.046^{* *} \\
(0.021)\end{array}$ & $\begin{array}{c}-0.143 * * * \\
(0.049)\end{array}$ & $\begin{array}{c}-0.143^{* * *} \\
(0.049)\end{array}$ & $\begin{array}{c}-0.214^{* * * *} \\
(0.056)\end{array}$ & $\begin{array}{c}-0.214 * * * \\
(0.056)\end{array}$ \\
\hline Scientific NPR & $\begin{array}{l}0.287 * * \\
(0.144)\end{array}$ & $\begin{array}{l}0.281^{*} \\
(0.144)\end{array}$ & $\begin{array}{l}0.161^{*} \\
(0.095)\end{array}$ & $\begin{array}{c}0.157 \\
(0.096)\end{array}$ & $\begin{array}{c}0.044 \\
(0.100)\end{array}$ & $\begin{array}{c}0.044 \\
(0.100)\end{array}$ & $\begin{array}{c}0.031 \\
(0.053)\end{array}$ & $\begin{array}{c}0.031 \\
(0.052)\end{array}$ & $\begin{array}{c}0.283 \\
(0.326)\end{array}$ & $\begin{array}{c}0.282 \\
(0.331)\end{array}$ & $\begin{array}{c}0.176 \\
(0.305)\end{array}$ & $\begin{array}{c}0.176 \\
(0.306)\end{array}$ \\
\hline Scientific Firm (publications) & $\begin{array}{l}-0.052 \\
(0.126)\end{array}$ & $\begin{array}{l}-0.041 \\
(0.127)\end{array}$ & $\begin{array}{l}-0.041 \\
(0.051)\end{array}$ & $\begin{array}{l}-0.036 \\
(0.053)\end{array}$ & $\begin{array}{c}0.055 \\
(0.083)\end{array}$ & $\begin{array}{c}0.052 \\
(0.084)\end{array}$ & $\begin{array}{l}0.039^{* *} \\
(0.048)\end{array}$ & $\begin{array}{l}0.037^{* * *} \\
(0.049)\end{array}$ & $\begin{array}{c}-0.629^{* * *} \\
(0.200)\end{array}$ & $\begin{array}{c}-0.606^{* * * *} \\
(0.202)\end{array}$ & $\begin{array}{c}-0.662 * * \\
(0.257)\end{array}$ & $\begin{array}{c}-0.659^{* *} \\
(0.262)\end{array}$ \\
\hline Firm size (employees) & $\begin{array}{l}0.026 \\
(0.034)\end{array}$ & $\begin{array}{c}0.027 \\
(0.034)\end{array}$ & $\begin{array}{l}0.009 \\
(0.014)\end{array}$ & $\begin{array}{l}0.010 \\
(0.014)\end{array}$ & 0.015 & 0.014 & 0.010 & $\begin{array}{l}0.010 \\
(0.013)\end{array}$ & $\begin{array}{r}-0.057 \\
(0.057)\end{array}$ & -0.056 & $\begin{array}{l}-0.058 \\
(0.046)\end{array}$ & -0.057 \\
\hline Constant & $\begin{array}{c}-1.009^{* *} \\
(0.460)\end{array}$ & $\begin{array}{c}-1.010^{* *} \\
(0.460)\end{array}$ & & & $\begin{array}{l}-0.550^{*} \\
(0.288)\end{array}$ & $\begin{array}{l}-0.551^{*} \\
(0.288)\end{array}$ & & & $\begin{array}{c}4.211^{* * * *} \\
(0.889)\end{array}$ & $\begin{array}{c}4.202 * * * \\
(0.892)\end{array}$ & $\begin{array}{c}4.693 * * * \\
(0.697)\end{array}$ & $\begin{array}{c}4.692^{* * * *} \\
(0.697)\end{array}$ \\
\hline Sigma & $\begin{array}{c}0.590^{* * * *} \\
(0.057)\end{array}$ & $\begin{array}{c}0.590^{* * *} \\
(0.057)\end{array}$ & & & $\begin{array}{c}0.538 * * * \\
(0.034)\end{array}$ & $\begin{array}{c}0.538^{* * *} \\
(0.034)\end{array}$ & & & & & & \\
\hline \begin{tabular}{|l|} 
Observations \\
\end{tabular} & 386 & 386 & 386 & 386 & 492 & 492 & 492 & 492 & 517 & 517 & 517 & 517 \\
\hline Wald Test (Fisher) & $65,91 * * *$ & $66,43 * * *$ & $3864,18^{* * *}$ & $3662,61^{* * *}$ & $53,57 * * *$ & $53,64 * * *$ & $990,18^{* * *}$ & $1886,93 * * *$ & $115,07^{* * *}$ & $276,15^{* * *}$ & $85,45 * * *$ & $88,39 * * *$ \\
\hline Log LH/Log PLH & $-170,68$ & $-170,42$ & $-159,34$ & $-158,97$ & $-315,68$ & $-315,65$ & $-292,71$ & $-292,68$ & & & & \\
\hline Pseudo R-2/ R-2 & 0,16 & 0,16 & 0,19 & 0,19 & 0,07 & 0,08 & 0,094 & 0,094 & 0.135 & 0.136 & 0.160 & 0.160 \\
\hline Observed P. & & & 0,204 & 0,204 & & & 0,37 & 0,37 & & & & \\
\hline Predicted P. & & & 0,184 & 0,184 & & & 0,36 & 0,36 & & & & \\
\hline Censoring \% & $79,53 \%$ & $79,53 \%$ & $79,53 \%$ & $79,53 \%$ & $71,56 \%$ & $71,56 \%$ & $71,56 \%$ & $71,56 \%$ & & & & \\
\hline
\end{tabular}

Note: all regressions include the technology dummies and time cohorts (not reported to save space). Robust Standard errors in parentheses for the models probit and ordinary least squares (ols).

${ }^{* * *} \mathrm{p}<0.01, * * \mathrm{p}<0.05,{ }^{*} \mathrm{p}<0.1$ 